\title{
Natural Organic Matter Removal in the Context of the Performance of Drinking Water Treatment Processes-Technical Notes
}

\author{
Djamel Ghernaout ${ }^{1,2}$ \\ ${ }^{1}$ Chemical Engineering Department, College of Engineering, University of Ha'il, Ha'il, KSA \\ ${ }^{2}$ Chemical Engineering Department, Faculty of Engineering, University of Blida, Blida, Algeria \\ Email: djamel_andalus@hotmail.com
}

How to cite this paper: Ghernaout, D. (2020) Natural Organic Matter Removal in the Context of the Performance of Drinking Water Treatment Processes-Technical Notes. Open Access Library Journal, 7: e6751. https://doi.org/10.4236/oalib.1106751

Received: August 26, 2020

Accepted: September 14, 2020

Published: September 17, 2020

Copyright $\odot 2020$ by author(s) and Open Access Library Inc.

This work is licensed under the Creative Commons Attribution International License (CC BY 4.0).

http://creativecommons.org/licenses/by/4.0/ (c) (i) Open Access

\begin{abstract}
Natural organic matter (NOM) is a very complicated mixture of organic compounds and is detected in all groundwater and surface waters. Besides NOM has a direct effect on health, it touches the performance of drinking water treatment processes (DWTPs) and so the safety of potable water. NOM may also disturb consumer satisfaction since it could participate in undesirable colors, tastes, and odors in potable water. This work aims to provide an insight into the effects of NOM on the global quality of drinking water, comprising its possible impacts on DWTPs and soon the safety of drinking water. It outlines the parameters that touch the level and property of NOM and examines the indexes to adopt when suggesting a NOM control strategy. Water source becomes highly polluted by organic compounds at a level that chemical oxygen demand is presently used to characterize surface water and biological treatment is suggested as a process for NOM removal in the DWTPs. Such behavior was not thinkable thirty years ago. The coagulation process remains importantly influenced by practical variables such as mixing conditions and $\mathrm{pH}$ control. Employing membrane processes instead of singular chemical oxidation and coagulation should be more promoted as water supplies become highly polluted in organic compounds.
\end{abstract}

\section{Subject Areas \\ Chemical Engineering \& Technology}

\section{Keywords}

Natural Organic Matter (NOM), Drinking Water Treatment Processes (DWTPs), Humic Acid, Fulvic Acid, Disinfection By-Products (DBPs), Blackfoot Disease 


\section{Introduction}

The health impacts of natural organic matter (NOM) are attributed to its influence on drinking water treatment processes (DWTPs) that are aimed to protect drinking water quality and public health [1] [2] [3]. NOM could touch techniques selected to eliminate or kill pathogenic microorganisms, participate in the generation of disinfection by-products (DBPs) and promote the growth of biofilms in the distribution system [4] [5] [6]. Further, its occurrence could form situations that lead to augmented lead and/or copper levels in treated water that are due to its effect on corrosion [7] [8] [9].

The treatability and reactivity of NOM change considerably throughout the world since each water source has unique characteristics [1] [10] [11]. As NOM is composed of several organic compounds, it cannot be quantified directly [12] [13] [14]. Nevertheless, there are some additional parameters that could be utilized to give a sign of the level and quality (i.e., physicochemical and biodegradability features) of NOM [15] [16] [17]. It is crucial to comprehend differences in NOM levels and quality with a view to choice, design, and run suitable DWTPs [18] [19] [20].

Suggesting an efficient NOM control strategy requires to be founded on an excellent comprehension of [1] [21] [22]: 1) changes in the level and feature of NOM in the source water, comprising those attributed to climate change, landscape changes or source water protection programs [23] [24] [24]; 2) NOM's effect on DWTPs and the influence of water treatment on NOM, for the full range of water quality conditions [26] [27] [28]; and 3) its possible effects on water quality in the distribution system [29] [30] [31].

Source-specific treatability investigations, comprising bench- and/or pilot-scale testing, are primary to define the most efficient treatment solution(s) to eliminate NOM, reduce its reactivity to produce DBPs, decrease its capability to participate in corrosion, and treat biologically stable water for distribution [1] [32] [33]. The shortage of a source-specific treatability investigation can lead to the adoption of unsuitable treatment, an augmentation in DBP levels after the application of the treatment, or other not planned outcomes [34] [35] [36]. Since water sources or DWTPs could vary over time, it is fundamental to usually observe the level and quality of NOM and to assess its influence on treatment, water quality, and distribution system circumstances [37] [38] [39].

This work aims to provide an insight into the effects of NOM on the global quality of drinking water, comprising its possible impacts on DWTPs and so on the safety of drinking water. It outlines the parameters that touch the level and property of NOM and examines the indexes to adopt when suggesting a NOM control strategy. It also furnishes specific guidance on treatment, monitoring, and water quality goals.

\section{Terminological Conventions}

Potable water guidelines, standards, and/or guidance from other national and 
international organizations could differ because of the date of the assessments as well as different policies and approaches [40] [41]. International organizations have not established numerical limits for NOM in drinking water [42] [43]. The United States Environmental Protection Agency's (U.S. EPA) Rule for disinfectants and Disinfection By-products requires removal of total organic carbon (TOC) by surface water facilities using conventional or lime softening water treatment with levels of TOC above $2 \mathrm{mg} / \mathrm{L}$ in their source water [44] [45]. Researchers suggest an optimized NOM removal as a means to minimize biofilm growth in the distribution system [46] [47]. The European Union regulations include TOC as a general water quality indicator; in some jurisdictions, chemical oxygen demand (COD) can be used in place of TOC [48] [49]. In Australia, guidance has been developed for water utilities to help them understand and control the impact of NOM [1] [50] [51].

\section{Facts on Natural Organic Matter (NOM) in Drinking Water}

\subsection{Natural Organic Matter (NOM) Background}

Natural organic matter (NOM) is a highly complicated mixture of organic compounds that differ considerably in terms of their physicochemical properties [52] [53] [54]. NOM exists normally in nature; further, it could be the consequence of human activities [55] [56] [57]. NOM is observed in particulate, colloidal and dissolved forms in all ground and surface waters, as well as in rainwater [58] [59] [60]. Besides exposure to NOM in nature is familiar and is related to direct health impacts (such as Blackfoot Disease [5] [61] [62]), the occurrence and features of NOM will possess great effects on DWTPs aimed at protecting public health [63] [64] [65]. NOM has a crucial action in drinking water treatment for several causes [1] [66] [67]. First, NOM could participate indirectly in health effects in several fashions, involving: 1) it provokes a coagulant demand that could conduct to suboptimal coagulation circumstances and decay of pathogen log reduction potential [68] [69] [70]; 2) it induces a chemical disinfectant demand or interferes with ultraviolet (UV) disinfection that could conduct to decay of pathogen log demobilization's potential [71] [72] [73]; 3) it generates regulated and non-regulated DBPs when it reacts with disinfectants [74] [75] [76]; 4) it promotes the growth of distribution system biofilms that could host pathogens [77] [78] [79] and; 5) it affects corrosion and could form circumstances that lead to elevations in the lead and/or copper levels as a consequence of corrosion of lead- and/or copper-bearing materials (e.g., piping, fittings) [80] [81] [82].

Moreover, DWTPs could be greatly touched by numerous NOM-provoked running problems, namely 1) augmented coagulant injection [83] [84] [85]; 2) bad floc generation or settling [86] [87] [88]; 3) shorter filter run times [89] [90] [91]; 4) more repeated backwashes [92] [93] [94] [95]; 5) augmented sludge formation [96] [97] [98]; 6) decreased hydraulic potential [99] [100] [101]; 7) membrane fouling [102] [103], higher transmembrane pressure and energy consumption, more frequent chemical cleaning and shorter membrane life [104] 
[105] [106]; and 8) decreased performance of adsorption and ion exchange processes [1] [107] [108].

Further, NOM could conduct to an elevation in consumer complaints since it could participate in the unwanted color, tastes, and odors in drinking water [1] [109] [110].

\subsection{Applying Risk Management Approaches}

To guarantee water safety, all DWTPs must apply a risk management procedure like the source-to-tap or water safety plan's procedure [1]. Such procedures need a systematic assessment that implies analyzing the water source, determining the treatment barriers that avert or decrease pollution, underlining the circumstances that could lead to pollution, and defining control actions [111]. Usable monitoring is then determined and usable/management protocols are established (like usual running plans of action, corrective actions, and incident reactions) [47]. Compliance monitoring is defined and other protocols to validate the water safety plan are applied (such as record keeping and consumer satisfaction) [47] [112]. Further, operator training is needed to guarantee the performance of the water safety plan at all conditions [9] [39] [113].

When suggesting and applying a risk management procedure, it is crucial to perceive how NOM could indirectly lead to health effects [1] [114]. NOM could augment prior to variations in turbidity and flow and could stay increased after turbidity and flow have returned to baseline circumstances [115] [116]. Therefore, variations in NOM can go undetected and a deterioration in pathogen log reduction could happen if appropriate monitoring is not used [117] [118] [119]. The aim of the NOM control procedure must be to guarantee protection from pathogens' hazards at all periods while reducing DBP [120], lead and copper levels, and controlling biofilm generation in the distribution system [121] [122] [123].

\subsubsection{Source-Specific Treatability Investigation}

Source-specific treatability investigations are proposed to define the most efficacious treatment solution(s) to adequately reduce NOM and to satisfy water quality targets in terms of microbial dangers, DBPs, biological stability, and corrosion control [1] [38] [110]. Evolving a powerful comprehension of the source water is requested to guarantee that a reliable, robust, and resilient treatment procedure is adopted [3] [91] [99]. Source-specific monitoring prior to facility design is required to estimate seasonal changes in NOM and forecast extreme circumstances due to alterations in climate [87] [98] [109]. The treatability study must implicate bench- and/or pilot-scale testing, as well as DBP formation potential trials that are representative of distribution system conditions [28] [79] [83].

\subsubsection{Source-Specific Monitoring}

The level and quality of NOM must be monitored in raw, treated and distribu- 
tion system water to guarantee that 1) treatment is regulated for NOM and turbidity removal, 2) DBP, lead and copper levels are as low as reasonably attainable and, 3) biofilm generation is reduced [1] [2] [115].

A source-specific monitoring plan has to be proposed to make certain that DWTPs are aware of 1) raw water quality alterations in terms of NOM level and quality, 2) the influence that NOM has on DWTPs through all water quality circumstances, 3) the effect that treatment has on NOM level and quality and, 4) the influences on distribution water quality [1] [5] [47].

The monitoring plan must be complete and implicate source characterization and operational and compliance monitoring (Table 1) [1] [47]. Further, it has to establish that water quality objectives are invariably satisfied for microorganisms' dangers, DBPs, biological stability, and corrosion control [29] [31] [32]. If possible, continuous online monitoring must be utilized for highly variable sources (that is to say, those that fluctuate with precipitation/snowmelt events) and critical processes (like coagulation) [55] [93] [108] (Table 2 and Table 3).

Table 1. Monitoring plan for source water assessments, treatment and operational monitoring, distribution system and suggested parameters and frequencies [1] [2] [47].

\begin{tabular}{|c|c|}
\hline Element & Description \\
\hline $\begin{array}{l}\text { Source water } \\
\text { assessments }\end{array}$ & $\begin{array}{l}\text { Source water assessments must be part of routine system assessments. They have to implicate a } \\
\text { comprehension of NOM sources in the watershed/aquifer, the circumstances that conduct to alterations } \\
\text { in the level and/or quality of NOM (such as precipitation/snowmelt events, algal blooms, drought, fire), } \\
\text { and the parameters that improve the reactivity of NOM to produce DBPs (like reaction variables, } \\
\text { water age, and inorganic compounds like ammonia, bromide, iodide, and sulfur). Surface and subsurface } \\
\text { sources must be analyzed in terms of NOM and inorganic compounds. The frequency of source water } \\
\text { characterization monitoring is a function of the variability of the source; further, } \\
\text { highly variable sources must be observed more frequently. }\end{array}$ \\
\hline $\begin{array}{c}\text { Treatment and } \\
\text { operational } \\
\text { monitoring }\end{array}$ & $\begin{array}{l}\text { The level and/or type of NOM could possess a crucial impact on the selection, design, } \\
\text { and operation of DWTPs. Indeed, DWTPs must be aware of } \\
\text { 1) the origin, occurrence, and fluctuations in NOM; } \\
\text { 2) interactions between NOM and other water constituents (like enhanced reactivity because of bromide); } \\
\text { 3) interactions with chemical products introduced during treatment (such as NOM forms a disinfectant } \\
\text { and coagulant demand that must be overcome to treat microbiologically safe drinking water); } \\
\text { 4) interactions between NOM and unit processes (like NOM fouls adsorbents and membranes) and; } \\
\text { 5) its influences on distribution system water quality (such as DBPs and biological stability). }\end{array}$ \\
\hline $\begin{array}{c}\text { Distribution } \\
\text { system }\end{array}$ & $\begin{array}{l}\text { Biodegradable organic matter (BOM) promotes biofilm development in the distribution system. } \\
\text { Biofilms could furnish habitat for the survival of microorganisms that may have passed through } \\
\text { DWTPs or entered the distribution system directly via an integrity breach. The most significant factors } \\
\text { for dominating the vegetation of bacteria in distribution systems are maintenance of a disinfectant } \\
\text { residual, limitation of BOM, and corrosion control. Keeping the physical/hydraulic integrity } \\
\text { of the distribution system and decreasing negative- or low-pressure events are other fundamental } \\
\text { components of a source-to-tap or water safety plan's approach. }\end{array}$ \\
\hline $\begin{array}{c}\text { Suggested parameters } \\
\text { and frequencies }\end{array}$ & $\begin{array}{l}\text { Table } 2 \text { summarizes proposed factors, sampling locations, and frequencies that could constitute the } \\
\text { foundation of a thorough monitoring program. A large number of the mentioned factors } \\
\text { (such as disinfectant residual, DBPs) are previously being monitored in most treatment plants } \\
\text { as part of a source-to-tap approach to treating safe drinking water. Additional variables are comparatively } \\
\text { plain to apply (like UV absorbance) and furnish fast findings. Proposed water quality aims are } \\
\text { summarized in Table 3. These are proposed as guidance only founded on the literature review. }\end{array}$ \\
\hline
\end{tabular}


Table 2. Suggested parameters for a comprehensive monitoring program for treating safe drinking water [1] [2] [47].

\begin{tabular}{|c|c|c|c|c|}
\hline \multirow{2}{*}{ Parameter } & \multirow{2}{*}{ Location } & \multicolumn{3}{|c|}{ Frequency } \\
\hline & & Variable source & Stable source & Ideal \\
\hline Organic color (true color) & Raw and treated & Daily & Weekly & Online \\
\hline UV absorbance (at $254 \mathrm{~nm}, \mathrm{UV}_{254}$ ) & Raw and filtered ${ }^{\mathrm{a}}$ & Daily & Weekly & Online \\
\hline Chemical oxygen demand (COD) & $\begin{array}{l}\text { Raw, treatment processes } \\
\text { and treated }\end{array}$ & Daily & Weekly & Online \\
\hline Dissolved or total organic carbon (DOC or TOC) & Raw and treated ${ }^{\mathrm{a}}$ & Weekly & Monthly & Online \\
\hline $\begin{array}{l}\text { Specific UV absorbance (SUVA)—calculate from } \\
\mathrm{UV}_{254} \text { and DOC }\end{array}$ & Raw and treated ${ }^{a}$ & Weekly & Monthly & Daily \\
\hline \multicolumn{5}{|l|}{$\begin{array}{l}\text { Inorganic compounds that can enhance the } \\
\text { reactivity of NOM to form DBPs: }\end{array}$} \\
\hline - Ammonia & & Quarterly & Quarterly & Quarterly \\
\hline - Bromide & \multirow{3}{*}{ Raw and treated } & Quarterly & Quarterly & Quarterly \\
\hline - $\quad$ Iodide & & Quarterly & Quarterly & Quarterly \\
\hline - Sulphur & & Quarterly & Quarterly & Quarterly \\
\hline Coagulant demand & Coagulation process $^{\mathrm{c}}$ & Daily & Daily & Online \\
\hline $\begin{array}{l}\text { Zeta potential or streaming current-when NOM } \\
\text { controls or influences coagulant dose }\end{array}$ & Coagulation process $^{c}$ & Online & Online & Online \\
\hline Disinfection by-products (DBPs) & Distribution system & \multicolumn{3}{|c|}{$\begin{array}{l}\text { Quarterly (measure DOC and inorganic } \\
\text { compounds on same day to calculate } \\
\text { specific DBP yields to assess NOM reactivity) }\end{array}$} \\
\hline \multicolumn{5}{|l|}{ Biological stability: } \\
\hline - $\quad$ Disinfectant residual & & Weekly & Weekly & Online \\
\hline $\begin{array}{l}\text { Biofilm formation rate-measured by adenosine } \\
\text { triphosphate (ATP) accumulated on mild steel coupons }\end{array}$ & Distribution system & Every two weeks & Monthly & \\
\hline $\begin{array}{l}\text { Corrosion rate-measured by linear polarization } \\
\text { resistance using mild steel coupons }\end{array}$ & & Monthly & Monthly & \\
\hline \multicolumn{5}{|l|}{ Influence of NOM on corrosion: } \\
\hline - Lead & \multicolumn{4}{|c|}{ In accordance with corrosion control program } \\
\hline - Copper & \multicolumn{4}{|c|}{ In accordance with corrosion control program } \\
\hline
\end{tabular}

${ }^{a}$ Disinfection will decrease UV absorbance without a related decrease in DOC. Therefore, to estimate the treated water SUVA, UV254 must be measured in filtered water pre-disinfectant addition and divided by the treated water DOC, then multiplied by $100 .{ }^{\mathrm{b}} \mathrm{COD}$ decreases across each treatment process. Monitoring locations will vary depending on the process trains in place (e.g., flocculation, clarification, and filtration) and the DWTP's continuous improvement program. 'Strict $\mathrm{pH}$ control is critical for NOM removal. As alkalinity affects $\mathrm{pH}$ control, $\mathrm{pH}$ and alkalinity are other important coagulation process monitoring parameters.

Table 3. Suggested treated water quality targets [1] [2] [47].

\begin{tabular}{cccc}
\hline Parameter & Units & $\begin{array}{c}\text { Source with high specific DBP yield } \\
\text { or extensive distribution system }\end{array}$ & $\begin{array}{c}\text { Source with low } \\
\text { specific DBP yield }\end{array}$ \\
\hline Organic color & $\mathrm{TCU}^{\mathrm{a}}$ & $5-10$ & $<15$ \\
UV absorbance (at $\left.254 \mathrm{~nm}, \mathrm{UV}_{254}\right)$ & $\mathrm{cm}^{-1}$ & $0.02-0.04$ & $0.02-0.07$ \\
UV transmittance & Percent & $90-95$ & $85-95$ \\
COD $^{\mathrm{b}}$ & $\mathrm{mg} / \mathrm{L} \mathrm{O}_{2}{ }^{\mathrm{c}}$ & $<5$ & $<5$ \\
DOC $^{\mathrm{d}}-$ for DBP control & $\mathrm{mg} / \mathrm{L} \mathrm{C}^{\mathrm{e}}$ & $<2$ & $<4$ \\
DOC $^{\mathrm{d}}$-for biological stability & $\mathrm{mg} / \mathrm{L} \mathrm{C}^{\mathrm{e}}$ & $<1.8$ & $<1.8$ \\
\hline
\end{tabular}

${ }^{\mathrm{a}} \mathrm{TCU}=$ true color units; ${ }^{\mathrm{b}} \mathrm{COD}=$ chemical oxygen demand; ${ }^{\mathrm{c}} \mathrm{O}_{2}=$ oxygen; ${ }^{\mathrm{d}} \mathrm{DOC}=$ dissolved organic carbon; ${ }^{\mathrm{e}} \mathrm{C}=$ carbon. 


\section{Definition of Natural Organic Matter (NOM)}

NOM is a very complicated mixture of organic compounds differing in polarity, acidity, charge density, and molecular mass [1] [2] [11]. Further, NOM could vary from biodegradable (i.e., labile or semi-labile) to less biodegradable (i.e., recalcitrant or refractory) [2] [11] [108]. Since NOM includes several organic compounds, it could be classified founded on its polarity (i.e., hydrophobic or hydrophilic) and acid/neutral/base features [2] [11] [108]. It is well established that such a procedure leads to six NOM portions, as mentioned in Table 4 [1] [124] [125]. Compound categories inside such portions have also been defined [109]. Compound categories furnish the highest degree of specificity possible, due to the number of compounds that can be existing [2] [11] [108].

The size and shape of NOM are affected by the $\mathrm{pH}$ and ionic strength of the water (Figure 1) [1] [20] [40]. At low pH and high ionic strength, NOM could possess a rigid, compact, coil shape [21] [24] [40]. However, at high $\mathrm{pH}$ and low ionic strength, it could possess a flexible linear filament shape [13]. Several compounds could show both hydrophobic and hydrophilic features (i.e., amphipathic) and have both negative- and positive-charged functional groups (i.e., amphoteric) [20] [40]. Portions carrying polysaccharides, proteins, and amino sugars possess the highest molecular weights $(>10 \mathrm{kDa})$, while the molecular weights of humic and fulvic acids usually range from $2 \mathrm{kDa}$ to $5 \mathrm{kDa}$ and from $0.5 \mathrm{kDa}$ to $2 \mathrm{kDa}$, respectively [126]. Further, lignin and tannin derivatives are also abundant in the high to medium molecular weight portions [21] [24] [40]. The smallest NOM portions $(<0.5 \mathrm{kDa})$ have a tendency to be hydrophilic compounds [1]. The most biodegradable portions comprise carbohydrates, amino acids, and proteins; however, the most recalcitrant include lignins, tannins, and terpenoids [21] [24] [40].

Table 4. NOM portions and compound classes [1] [124] [125].

\begin{tabular}{|c|c|}
\hline Fraction & Compound classes \\
\hline & Hydrophobic \\
\hline \multirow{4}{*}{ Acids } & $\underline{\text { Strong acids }}$ \\
\hline & $\begin{array}{l}\text { Humic and fulvic acids, high molecular weight alkyl monocarboxylic } \\
\text { and dicarboxylic acids, aromatic acids }\end{array}$ \\
\hline & $\underline{\text { Weak acids }}$ \\
\hline & $\begin{array}{c}\text { Phenols (e.g., lignin), tannins, medium molecular weight alkyl monocarboxylic } \\
\text { and dicarboxylic acids }\end{array}$ \\
\hline Bases & Proteins, aromatic amines, high molecular weight alkyl amines \\
\hline Neutrals & $\begin{array}{l}\text { Hydrocarbons (e.g., terpenoids), aldehydes, } \\
\text { high molecular weight methyl ketones and alkyl alcohols, ethers, furans, pyrrols }\end{array}$ \\
\hline \multirow[b]{2}{*}{ Acids $^{\mathrm{a}}$} & Hydrophilic \\
\hline & $\begin{array}{l}\text { Hydroxyl acids, sugars, sulphonics, } \\
\text { low molecular weight alkyl monocarboxylic and dicarboxylic acids }\end{array}$ \\
\hline Bases & Amino acids, purines, pyrimidines, low molecular weight alkyl amines \\
\hline Neutrals & $\begin{array}{l}\text { Proteins, carbohydrates (e.g., polysaccharides, low molecular } \\
\text { weight alkyl alcohols, aldehydes and ketones), cellulose and cellulose derivatives }\end{array}$ \\
\hline
\end{tabular}

${ }^{a}$ Hydrophilic acids can also be reported as transphilic NOM [1]. 


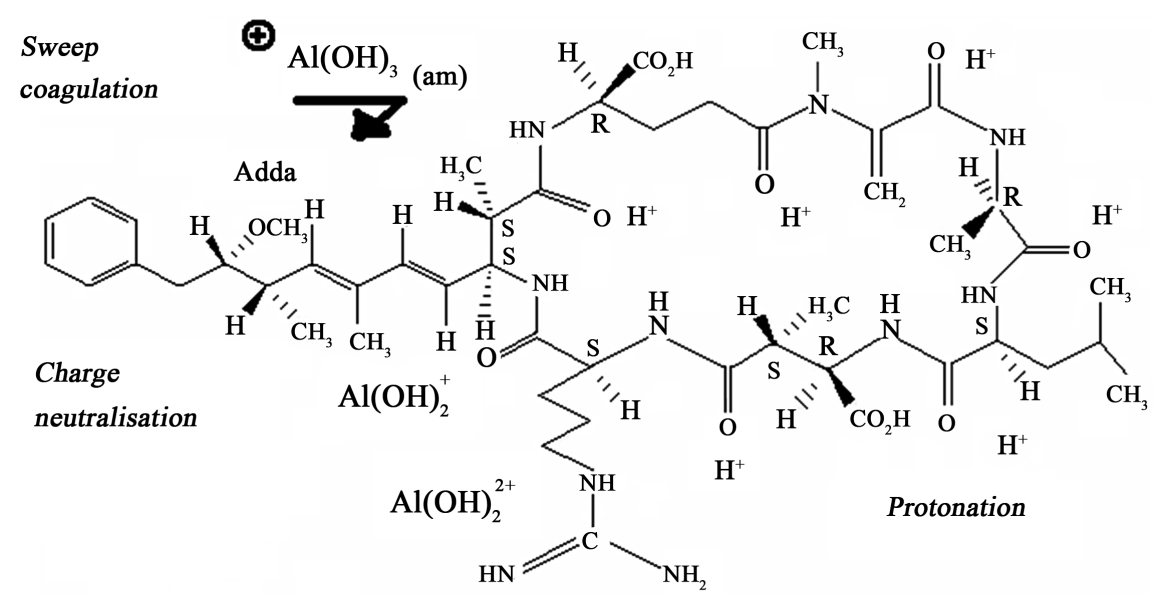

Adda: 3-amino-methoxy-10phenyl-2,6,8-trimethyl-deca-4,6-dienoic acid

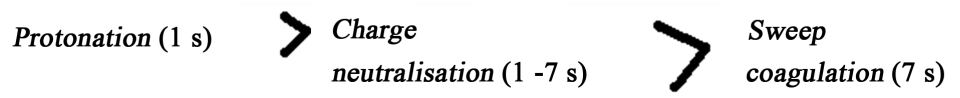

Figure 1. Coagulation mechanisms for microcystin-LR removal [5].

\section{Origins and Presence of Natural Organic Matter (NOM)}

The concentration and feature (that is to say, physicochemical and biodegradability characteristics) of NOM could be so changing due to the different hydrological and biogeochemical processes that influence the origins of NOM [40] [127]. Such a phenomenon is in short discussed in the Sections 6 and 7, along with factors that have historically been employed to measure organic matter, including 1) organic color, as a measure of humic and fulvic acids and, 2) organic carbon, the fundamental constituent of NOM [1] [13] [40]. Additional variables that could be utilized to quantify and characterize NOM are reviewed later in this work.

\subsection{Origins of Natural Organic Matter (NOM)}

There are two natural origins of NOM: allochthonous (i.e., derived from the terrestrial ecosystem) and autochthonous (i.e., derived from the plants and microorganisms growing in the water body) [40] [127]. Further, anthropogenic (human) activities could participate in NOM [1].

Allochthonous NOM is transmitted to aquatic mediums as precipitation moves through the atmosphere and vegetative canopy, infiltrates organic soil layers, and percolates downward through mineral soil layers [1] [40]. Soil humus, plant litter, microbial biomass, and root exudates participate in allochthonous NOM [128]. Allochthonous NOM has a tendency to be naturally hydrophobic [11].

Autochthonous NOM is extracted from phytoplankton, algae, cyanobacteria and macrophytes (i.e., plants attached to or rooted in the substrata of lakes and streams) and can account for $5 \%-100 \%$ of the DOC concentration, following some circumstances [2] [129]. When allochthonous inputs are increased, like in 
colored water sources or during precipitation/snowmelt events (i.e., stormflow situations), the fraction of autochthonous NOM has a tendency to be small [1]. On the contrary, when allochthonous inputs are small, like in limpid water sources or during dry periods when there is little runoff, the fraction of autochthonous NOM has a tendency to be elevated [1]. Autochthonous NOM involves a large domain of compounds (mono- and polysaccharides, amino acids, peptides, proteins, nucleic acids, organic acids, lipids, and fatty acids) [130] [131]. DOC is formed via the generation and degradation of the microbial and plant biomass inside water sources [132] [133]. Algal inputs have a tendency to prevail in wide lakes, while macrophytes have a tendency to be the main contributor in small lakes [134]. Algal and cyanobacterial blooms, especially, constitute a source of DOC that could be periodic and intense [12] [16] [29]. Cyanobacterial blooms can be related to more water quality problems because of the possible occurrence of cyanobacterial toxins [57] [91] [109]. Autochthonous NOM has a tendency to be naturally hydrophilic and nitrogen-rich [11].

Anthropogenic origins of NOM comprise septic systems, wastewater treatment and stormwater discharges, agricultural runoff, and industrial discharges. Anthropogenic NOM is noted to be naturally hydrophilic [135] and nitrogen-rich [136]. Watersheds heavily influenced by anthropogenic sources may observe a reduction in TOC or DOC following the amelioration of wastewater or stormwater treatment [1] [137].

Raw water NOM concentrations are regarded as the net influence of hydrological and biogeochemical processes in the watershed or aquifer [138]. The concentration and quality of NOM and thus its treatability (that is to say, the possibility to be eliminated) and reactivity (that is to say, the probability to produce DBPs) change considerably from one source to another, as each water source possesses unique characteristics. For instance, researchers [139] mentioned that two lakes in Nova Scotia only $1 \mathrm{~km}$ apart had TOC concentrations of 5.6 and $17.2 \mathrm{mg} / \mathrm{L}$, respectively. In the low TOC lake, the retention time was 1.27 years and organic soils were absent; however, in the high TOC lake, the retention time was 0.35 years and organic soils were present. Longer retention times have a tendency to decrease the DOC concentration. Nevertheless, scientists [140] affirmed that the evapoconcentration of refractory NOM conducted to augmented DOC concentrations with elevating retention time in the sub-humid and semi-arid zones of Alberta. Several researchers have found identical results concerning the variability and uniqueness of NOM for sources in close proximity to each other [1] [137].

As a rule, NOM concentrations are lower in groundwater sources since the organic matter is exposed to adsorption and microbial decomposition phenomena as it is transported across the soil [125] [127]. Nevertheless, such phenomena are restricted by the quantity of biodegradable NOM that is existing. On the contrary, some groundwater flows through aquifer materials that are rich in organic matter leading to high organic carbon concentrations [141] [142]. Fol- 
lowing some published documents, organic carbon concentrations in some North American groundwaters range from $<0.1$ to $22 \mathrm{mg} / \mathrm{L}$ [1]. Seasonal variability could happen on a per well basis, so reliance on a single sample to represent groundwater quality may be confusing [1].

The NOM in groundwater has a tendency to be more hydrophilic and recalcitrant naturally [1] [143] and almost as reactive as surface water NOM on an $\mathrm{mg} / \mathrm{L}$ DOC basis [137] [144]. For instance, researchers [1] noted particular DBP yields of $67 \mu \mathrm{g}$ trihalomethanes (THMs)/mg DOC and $29 \mu \mathrm{g}$ haloacectic acids (HAAs)/mg DOC for small groundwater supplies utilizing chlorination. Groundwater sources could possess higher levels of bromide or iodine that could participate in their capacity to produced DBPs [1] [145].

Consequently, localized circumstances possess an extremely crucial contribution in setting the level and quality of NOM [137] [145]. Presence facts discussed above call attention to the variability that could happen, with or without a related alteration in DOC level [1] [146] [147]. Further, the facts illustrate that even if groundwater has a tendency to possess lower NOM levels, some sources could possess increased levels. Therefore, both surface and subsurface sources have to be analyzed.

\subsection{Presence of Natural Organic Matter (NOM)}

The level and quality (physicochemical and biodegradability characteristics) of NOM could be greatly changing due to the several hydrological and biogeochemical phenomena that export, form, or decompose NOM (Table 5, Table 6) [1].

Table 5. Presence of natural organic matter (NOM): Level and quality [1].

\begin{tabular}{|c|c|}
\hline Element & Description \\
\hline Level & $\begin{array}{l}\text { Researchers [1] summarized the monitoring data that were accessible } \\
\text { for their review. Table } 6 \text { displays the DOC monitoring data collected in } \\
2009 \text { and } 2010 \text { from chosen drinking water sources in every region of } \\
\text { Canada [1]. Such facts as well show lower DOC levels in groundwater } \\
\text { with a minimal change between raw and treated water concentrations. } \\
\text { For the surveyed surface water supplies, average treated water DOC } \\
\text { ranges from } 3.2-3.4 \mathrm{mg} / \mathrm{L} \text { in summer and } 2.8-3.5 \mathrm{mg} / \mathrm{L} \text { in winter. }\end{array}$ \\
\hline Quality & $\begin{array}{l}\text { Numerous investigations have analyzed the six NOM portions (see Table 4) } \\
\text { found in several Canadian source waters [1]. Researcher [148] examined } \\
\text { a lake source in Nova Scotia and detected important temporal variability } \\
\text { in the six NOM fractions; however, DOC levels stayed low with minimal } \\
\text { alteration. Investigators [149] investigated a river source in Manitoba } \\
\text { and as well noted important temporal variability in the six NOM } \\
\text { portions but with fluctuations in DOC levels. Other researches established } \\
\text { that NOM quality could change greatly by location [1]. The findings of } \\
\text { such fractionation investigations proved the variability that could happen } \\
\text { in the NOM feature-with or without a related modification in the } \\
\text { DOC level. Moreover, the findings show that the hydrophilic neutral } \\
\text { portion could sometimes include a considerable part of NOM. } \\
\text { Such a part could be especially troublesome [1]. }\end{array}$ \\
\hline
\end{tabular}


Table 6. Dissolved organic carbon (DOC) facts from the health Canada national survey [1].

\begin{tabular}{cccccccccc}
\hline \multirow{2}{*}{$\begin{array}{c}\text { Source } \\
\text { type }\end{array}$} & $\begin{array}{c}\text { Sample } \\
\text { type }\end{array}$ & \multicolumn{3}{c}{ Summer DOC $(\mathrm{mg} / \mathrm{L})^{\mathrm{a}}$} & \multicolumn{4}{c}{ Winter DOC $(\mathrm{mg} / \mathrm{L})^{\mathrm{a}}$} \\
\cline { 3 - 9 } Well & Raw & 18 & 0.7 & 1.8 & 4.0 & 16 & 0.7 & 2.0 & 4.4 \\
& Treated & 17 & 0.8 & 1.6 & 4.3 & 15 & 0.8 & 1.7 & 4.5 \\
& Raw & 21 & 4.0 & 7.3 & 11.5 & 20 & 4.6 & 6.6 & 9.7 \\
\multirow{2}{*}{ Lake } & Treated & 21 & 2.8 & 3.2 & 5.2 & 20 & 2.4 & 3.5 & 5.6 \\
& Raw & 26 & 5.9 & 7.2 & 14.2 & 21 & 4.7 & 5.8 & 10.0 \\
\multirow{2}{*}{ River } & Treated & 26 & 2.6 & 3.4 & 6.0 & 21 & 2.6 & 2.8 & 5.4 \\
\hline
\end{tabular}

${ }^{\mathrm{a}}$ Method detection limit of $0.2 \mathrm{mg} / \mathrm{L}$.

\section{Ecological Consequences}

Ecological parameters could modify the NOM level and/or the special role of allochthonous, autochthonous, or anthropogenic inputs and that way alter its quality. Such alterations may touch water sources and water treatment techniques (Table 7) [1].

Moreover, investigators have observed that wildfires could lead to long term ( $>10$ years) water quality regression that considerably modifies the level and quality of NOM, and that manner greatly affects water treatment technology [158]. Wildfires are predicted to augment in frequency because of alterations in climate [159]. Additional water quality alterations that are predicted to take place because of a modifying climate and exacerbate NOM-related effects involve augmented water temperature; augmented variability in runoff; and elevated nutrient loading due to extreme runoff events [159]. An elevation in the frequency and severity of algal development and cyanobacterial blooms is forecast to be related to these modifications [1] [159].

\section{Effects of Natural Organic Matter (NOM)}

Even if NOM has direct health effects (such as Blackfoot Disease [5] [61] [62]), it greatly influences drinking water treatment and could participate in indirect health effects, as well as operational and aesthetic issues [1].

\subsection{Indirect Health Effects}

\subsubsection{Pathogen Log Reductions}

As a rule, potable water treatment involves physical removal barriers (such as clarification and filtration) that are assigned pathogen "log removal" credits, and inactivation barriers (primary disinfection) that are assigned "log inactivation" credits. NOM greatly affects both [1].

For chemically founded clarification/filtration techniques, NOM appeals to a coagulant demand that must be overcome before neutrally charged floc particles could generate [1] [11] [108]. Neutrally charged floc particles are required for 
Table 7. Environmental considerations [1].

\begin{tabular}{|c|c|}
\hline Ecological parameter & Description \\
\hline $\begin{array}{c}\text { Seasonal or } \\
\text { weather-related } \\
\text { impacts }\end{array}$ & $\begin{array}{l}\text { Several scientists noted an elevation in NOM level and a modification in its quality following snowmelt, } \\
\text { spring runoff, or heavy rain [1] [137]. DOC levels could quickly augment four- to five-fold during } \\
\text { precipitation/snowmelt events that flush terrestrial NOM into a water body [125]. The highest levels could } \\
\text { happen in the summer and autumn during which temperatures are warmer, biological activity is high, } \\
\text { and high-intensity/short-duration rainstorms are frequent [1]. } \\
\text { Precipitation and snowmelt events could greatly damage the coagulation technique for several causes. } \\
\text { First, water quality alters during stormflow circumstances that provoke difficult coagulation disorders } \\
\text { (such as pH, alkalinity, ionic strength, divalent ion concentration). Second, NOM has been shown to augment } \\
\text { prior to alterations in turbidity or flow and could stay increased after turbidity and flow have returned to } \\
\text { baseline circumstances. Therefore, if the coagulant injection is controlled founded on flow or turbidity, } \\
\text { coagulant may be under-dosed, conducting to suboptimal coagulation circumstances. It is well established } \\
\text { that suboptimal coagulation situations conduct to an important failure in pathogen log removal credits. } \\
\text { Rainstorms during winter or spring could be challenging since low temperatures could diminish the } \\
\text { performance of the coagulation technique [1]. }\end{array}$ \\
\hline $\begin{array}{l}\text { Additional } \\
\text { ecological } \\
\text { impacts }\end{array}$ & 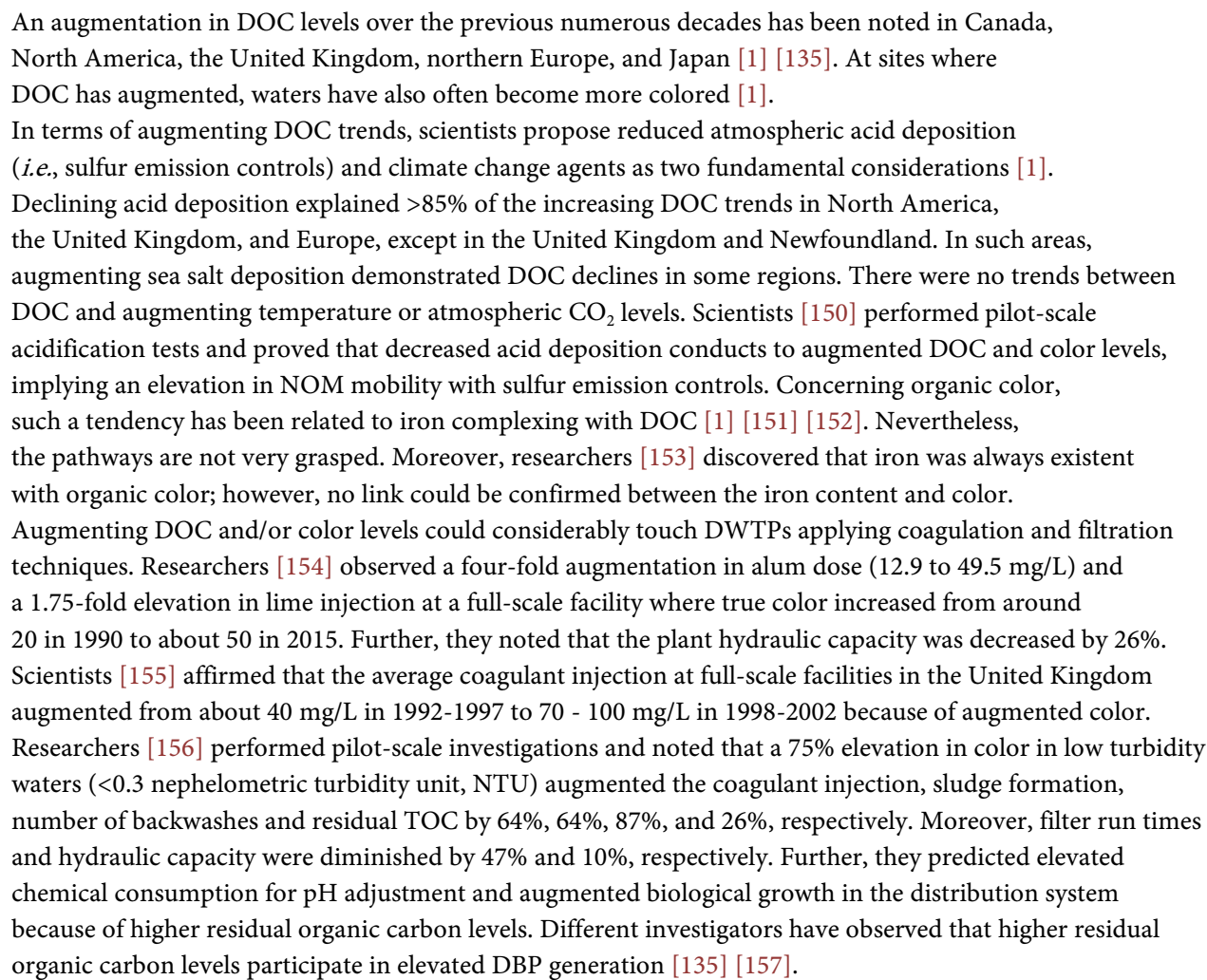 \\
\hline
\end{tabular}

filters to run correctly and satisfy turbidity requirements for pathogen removal [32] [51] [160]. NOM levels could augment without modification in turbidity or flow and thus may go undetected. In addition, augmented NOM levels prompt the necessity to elevate the coagulant injection to attain neutrally charged floc particles; apart from that, suboptimal coagulation circumstances occur and a reduction in pathogen log removal could happen [1].

Researchers [1] noted Cryptosporidium breakthrough and an elevation in particle counts $(2-5 \mu \mathrm{m}, 5-10 \mu \mathrm{m}$ and $10-15 \mu \mathrm{m})$, at a full-scale direct filtration treatment plant, because of augmentation in color in the source water. Sev- 
eral investigators noted the breakthrough of particles $>2 \mu \mathrm{m}$ at the pilot-scale during periods of increased TOC [161]. Different researches mentioned that Cryptosporidium removal via clarification/filtration could considerably suffer during suboptimal coagulant circumstances (e.g., treatment effectiveness reduced by 2.0 to 3.4 logs as juxtaposed with optimal parameters) [1].

\subsubsection{Generation of Disinfection By-Products (DBPs)}

Chemical oxidants and disinfectants react with NOM to produce very toxic DBPs [1] [38] [110]. All NOM portions participate in DBP generation, even if certain portions produce more DBPs than other portions [162] [163]. Certain non-regulated DBPs are more cytotoxic and genotoxic than regulated DBPs such as THMs and HAAs [115] [164]. Even if THMs and HAAs could be utilized as measures for the occurrence of additional DBPs, it is crucial to realize that their generation mechanisms and reaction rates are various [1].

\subsubsection{Biological Stability}

The biological stability of potable water deals with the notion of preserving microbiological water quality from the point of treatment to the point of consumption [1]. Heterotrophic organisms constitute the majority of bacteria in potable water and draw their energy for growth, multiplication, and production of biofilm matrix materials from the decomposition of organic carbon compounds [165]. BOM promotes bacterial growth and biofilm development in the distribution system and premise plumbing that could conduct to problems, which have public health importance. Biofilms give a habitat for the survival of fecal pathogens that may have passed through drinking water treatment barriers or entered the distribution system directly via an integrity breach. Enteric viruses and protozoa could be observed in biofilms; even if such organisms cannot grow in such medium, they can aggregate and be liberated over an extended period [1].

Further, treatment techniques greatly touch the composition and level of organic nutrients. For instance, oxidants like $\mathrm{Cl}_{2}$ and $\mathrm{O}_{3}$ form biodegradable products upon reaction with NOM [90] [137]. Ozone converts NOM to BOM; therefore, biologically active filtration could be needed to stabilize treated water. Moreover, $\mathrm{Cl}_{2}$ could react with the organic matter by that means augmenting the quantities of assimilable organic carbon (AOC) and biodegradable DOC (BDOC) which could worsen the issue of biofilm development in distribution systems [1] [137].

\subsubsection{Corrosion Effects}

Corrosion is the decay of a material that results from a response with its medium. In potable water distribution systems, corrosion could be provoked by some parameters, comprising the kind of materials utilized in pipes and fittings, the age of the piping and fittings, the stagnation time of the water and the water quality in the system (particularly $\mathrm{pH}$ and alkalinity) [47] [53]. Additional potable water quality indicators that could affect corrosion involve temperature, calcium, free chlorine residual, chloramines, chloride, sulfate, and NOM [1]. 
NOM influences lead and copper corrosion [1] [166]. The impacts of NOM on metal surfaces could be changed. NOM could furnish a protective film, reducing corrosion (particularly over a long timeframe), or it could augment corrosion via a set of pathways 1) NOM can complex with $\mathrm{Ca}^{2+}$ and prohibit protective scale generation or, 2) NOM can run as a food source for microbes that can in turn attack the pipe surface and worsen corrosion [1].

\subsection{Running Problems}

\subsubsection{Coagulation Technique}

The coagulation process aims to neutralize the charge (i.e., destabilize) of colloids (comprising microorganisms) at a level that they efficiently assemble through the flocculation stage and are then retained by clarification and/or filtration [2] [7] [93]. Further, coagulation handles retaining NOM via a phase modification that transforms dissolved organic matter (DOM) into particles: either directly by precipitation or by adsorption onto particles formed by the coagulant [11] [12] [17]. When metal coagulants are introduced into the water, chemical responses happen with both particles and NOM. Thus, when a coagulant is injected, the NOM works as a ligand that complexes the positively charged metal ions, exercising a coagulant demand that should be overcome before flocculation could take place [18] [29] [37]. Further, the type of NOM possesses a crucial effect on the coagulation efficiency. For instance, a two-fold augmentation in coagulant injection is requested to coagulate equal mass concentrations of fulvic acids as compared with humic acids [167].

Consequently, coagulation has to be adopted as a "combined" method that considers both NOM and colloids (i.e., turbidity) while having regard to their different coagulation properties [93]. As an illustration, for the $\mathrm{pH}$ conditions of most water sources ( $\mathrm{pH} 6-8$ ), NOM and colloids carry a negative charge that becomes more negative with augmenting $\mathrm{pH}$. Nevertheless, the negative charge of NOM is usually between 5 - $15 \mu \mathrm{eq} / \mathrm{mg}$ carbon, whilst that of colloids is between 0.05 - $0.5 \mu \mathrm{eq} / \mathrm{mg}$ particle, following the colloid type [1]. Coagulant injection is controlled by NOM, not by turbidity. Turbidity must augment considerably, in the absence of a related NOM elevation, for turbidity to control the coagulant injection. Since NOM levels can quickly augment four- to five-fold during storm events, it is fundamental that DWTPs possess an excellent comprehension of NOM's influence on coagulant injection [168]. The inability to set the coagulant injection following an alteration in NOM can participate in suboptimal coagulation circumstances and a reduction in pathogen log removal capacity [1].

\subsubsection{Membrane Treatment}

It is well established that NOM is in charge of membrane fouling that could considerably damage water treatment functioning [1] [102] [103]. As a rule, the hydrophilic neutral fraction of NOM, including polysaccharides and proteins in macromolecular and/or colloidal form (i.e., biopolymers), is in charge of membrane fouling [104] [105] [169]. It is suggested that once fouling is begun by 
biopolymers, a lowering in electrostatic forces lets hydrophobic NOM to adsorb to the membranes, conducting to more fouling [169]. Scientists [170] affirmed that biopolymer levels around $0.1 \mathrm{mg} / \mathrm{L}$ conducted to reversible (i.e., removable by backwashing/air scour) and irreversible (i.e., removable by chemical cleaning) fouling. Researchers [171] noted that fouling by protein-like substances that were not detected in the feed water is related to low levels (detection limit not given).

Additional parameters that influence membrane fouling implicate membrane properties (like the type of membrane, pore size distribution, material, surface charge, hydrophobicity), running circumstances (such as flux, recovery, pretreatment, backwashing, chemical cleaning), and water quality (like $\mathrm{pH}$, ionic strength, concentration, and character of the foulant) [1].

DWTPs must possess an excellent comprehension of the manner by which the NOM in their source water will interact with membranes to avert configurations that cause important fouling [1]. Pretreatment could be requested to decrease biopolymer levels [169]. Pretreatment remains to be adapted to each individual source since effectiveness is source-specific [172]. In order to eliminate aggregated foulant, a program of methodical backwashing and periodic chemical cleaning, employing appropriate foulant-based cleaning chemicals has to be as well applied [1].

\subsubsection{Aesthetic Problems}

There is no doubt that NOM is in charge of aesthetic troubles like color, taste, and odor [1] [40].

Color provoked by the occurrence of organic matters could take place in both surface and groundwaters [1] [40] [173]. Organic color has a tendency to be formed by the occurrence of humic and fulvic acids, which are black- to yellow-colored substances [40] [124]. Researchers [153] affirmed that $87 \%$ of the substances in charge of color in 10 U.S. sources were colloidal and $3.5-10 \mathrm{~nm}$ in size. Conversely, scientists [174] affirmed that $40 \%$ of the compounds in charge of color in seven Finnish sources were $<10 \mathrm{kDa}$ (about $1 \mathrm{~nm}$ ). Highly colored sources have a tendency to possess a higher level of high molecular weight humic acids, which may account for these dissimilarities in size distribution [1]. Fulvic acids constitute a more complicated mixture of low molecular weight compounds that are more hydrophilic than humic acids, and they possess an important effect on the demanded coagulant injection. In addition, a bigger part of fulvic acids is non-coagulable at any $\mathrm{pH}$ or coagulant injection [1]. Since humic and fulvic acids are serious DBP precursors, convenient color elimination could be required to satisfy DBP guidelines [108] [145]. For instance, investigators [173] detected THM formation potentials of $250-262 \mu \mathrm{g} / \mathrm{L}$ (7-day formation potential test at $20^{\circ} \mathrm{C}$ and at around $\mathrm{pH} 8$ ) for a highly colored groundwater supply with naturally occurring humic and fulvic acids (TOC $=3.93-4.70 \mathrm{mg} / \mathrm{L}$; UV absorbance $=0.1829-0.1907$ )

Moreover, tastes and odors could be formed by volatile compounds generated 
by the microbial biomass (such as actinomycetes, cyanobacteria, fungi), which is washed in from the terrestrial medium or naturally exists in the aquatic system/aquifer [1] [29]. Twenty years ago, scientist [175] specified about 200 volatile organic compounds that generate unwanted tastes and odors. Terpenoids (such as geosmin and 2-methylisoborneol), sulfides and polyunsaturated fatty acids were defined as the most odorous. Different scientists recognized pyrimidines as troublesome [176]. Actinomycetes and fungi could survive in the soft deposits (i.e., accumulated deposits containing organic and inorganic matter) of water distribution systems. Thus, the distribution system can represent a source of taste and odor issues.

In addition, $\mathrm{Cl}_{2}$ responses with $\mathrm{NOM}$ can participate in tastes and odors [4] [44] [77]. Especially, nitrogen-rich NOM could produce odorous aldehydes, $N$-chloraldimines, or nitriles if convenient circumstances subsist with either $\mathrm{Cl}_{2}$ or chloramines [1]. Reaction mechanisms are a function of the selection of disinfectant, disinfectant to amino acid molar ratio, $\mathrm{pH}$, temperature, and reaction time [115] [118]. Amino acids have been recognized as the essential odor-causing precursor and they could be liberated by the lysis of bacterial or algal cells or when proteins are oxidized [1]. Table 8 furnishes the odor threshold levels that have been mentioned in the literature for such compounds. Since nitriles possess much higher odor threshold levels (see Table 8), they are not usually involved in taste and odor events [1]. Further, odor-causing compounds (like terpenoids) and precursors (such as amino acids and proteins) are not efficiently eliminated by traditional treatment [28] [49]. Therefore, additional techniques should be needed to reduce tastes and odors [5] [10] [38]. When odorous compounds are produced, they could remain in the distribution system for more than 500 hours $(\approx 21$ days $)$ at $15^{\circ} \mathrm{C}[1]$. Their levels could as well augment in the distribution system because of the liberation of amino acids or peptides from the biofilm [1]. To help DWTPs evaluate and reduce unpleasant tastes and odors, guidance material is obtainable elsewhere [177].

\section{Measurement and Characterization}

An efficient NOM control procedure requests an excellent comprehension of the origin, presence and change that happens in the source water [178]. DWTPs must possess a very comprehension of 1) their water source and the type and formation of NOM; 2) if NOM changes seasonally or with precipitation/snowmelt events and; 3) how NOM interacts with treatment processes [1].

Table 8. Odor threshold levels known for NOM-related compounds [1].

\begin{tabular}{ccc}
\hline Odorous by-product & Odor threshold level $(\mu \mathrm{g} / \mathrm{L})$ & Reported odor \\
\hline Aldehydes & $0.15-30$ & Swampy swimming pool \\
$N$-chloraldimines & $0.20-3$ & Floral swimming pool \\
Nitriles & $210-430$ & \\
\hline
\end{tabular}




\subsection{Notices for Measuring Natural Organic Matter (NOM)}

Further, TOC measures all organic carbon in a water sample and is the sum of particulate organic carbon and DOC; the latter is practically described as the organic carbon that could pass through a $0.45 \mu \mathrm{m}$ filter [1] [179]. Because the filter could drain some organic carbon to the sample, it is suggested that at least 50 $\mathrm{mL}$ of organic-free water be passed through the filter and filter assembly before filtering the DOC sample [180]. TOC and DOC are quantified indirectly from the $\mathrm{CO}_{2}$ that is generated by UV-catalyzed chemical oxidation or by high-temperature combustion.

Moreover, UV-visible light absorbance at 254, 350, and $440 \mathrm{~nm}$ could be linearly related to the DOC level in some freshwater systems. Nevertheless, linear correlations remain less probably to be encountered in sources with strong autochthonous or anthropogenic inputs or where DOC has been largely decomposed by natural UV light (such as long retention time in the lake) [181]. Quantifying $\mathrm{UV}_{254}$ has historically been utilized in the water industry [1]. Samples have to be filtered to retain particle-related alterations in UV absorbance [179]. As a rule, it is mostly tolerated that an alteration in UV absorbance gives an excellent sign of modifications in NOM [182]. Watching online (or daily) UV absorbance furnishes worthy data to engineers on uncertain effects to the coagulant injection, since NOM levels may vary without any detected fluctuation in the flow (or turbidity) [1]. Apart from that, engineers are not conscious of coagulant under-dosing until turbidity spikes are noted in clarified water or filter effluent. It stays fundamental that relationships be proposed on a source-specific basis since the link between NOM and UV absorbance is unique to each source [1]. In several circumstances, it is not easy to determine a relationship between $\mathrm{UV}_{254}$ and DOC [181]. Watching UV-visible light absorbance over a larger domain of wavelengths can be more suitable in numerous situations [182]. On the other hand, the loss of a relationship could be related to the occurrence of NOM that has low UV absorbance (like proteins and sugars) or a high nitrate amount, which may interfere with this quantification. Watching UV-visible light absorbance over a larger domain of wavelengths could as well give a more sophisticated characterization [1].

UV transmittance is a proportional measure of how much light passes through a water sample (at $\mathrm{UV}_{254} \mathrm{~nm}$, usually through a $1 \mathrm{~cm}$ path length) juxtaposed with how much light passes through pure deionized water (which has a UV transmittance of 100\%) [1]. Since UV absorbance and UV transmittance are mathematically related as per Equation (1), no date is lost via selecting one parameter over the other [183]:

$$
\text { UV absorbance }\left(\mathrm{cm}^{-1}\right)=2-\log _{10} \mathrm{UV} \text { transmittance }(\%)
$$

On the other hand, COD helps to provide some evidence of the level of oxidizable organic matter in a water sample [1]. With reference to past events, the COD test method (utilizing potassium dichromate) was not responsive sufficiently for potable water. Methods that are more responsive have since been 
suggested. Data on the average oxidation state of organic carbon during water treatment could as well be obtained employing a ratio of the molar concentrations of COD and TOC/DOC [1].

With reference to past events, color has been quantified utilizing colorimetric techniques. The occurrence of suspended solids (like clay, iron and manganese oxides) could attribute water the appearance of color and must be retained by filtering the sample through a $0.45 \mu \mathrm{m}$ filter before measurement of NOM-related organic color (like color-related mainly to the existence of humic and fulvic acids). A filtered sample is practically described as "true color" [179]. Investigators have as well employed visible light absorbance at $420 \mathrm{~nm}$ as a measure for organic color [150]. Nevertheless, a $450-465 \mathrm{~nm}$ wavelength is suggested as a standard spectrophotometric method [179]. The spectrophotometric procedure needs that samples be filtered through a $0.45 \mu \mathrm{m}$ filter [179]. Juxtaposing true and apparent color findings could let DWTPs decide if color objections are NOM-related. The apparent color applies to unfiltered samples and is a helpful quantification to evaluate the existence of iron and manganese oxides in the distribution system [1].

Quantifying the above-mentioned variables stays easy and quick to do, and numerous tests could be automated. Such measurements could show a modification in water quality is happening; nevertheless, they do not provide data concerning the nature of the NOM. Scientists noted that $U_{254}$ divided by the $\mathrm{mg} / \mathrm{L}$ of DOC might be a useful index of the NOM feature [1]. Later, such a notion became familiar as specific UV absorbance (SUVA). Further, calculating the specific color (true color divided by mg/L DOC) could furnish helpful data [1].

\subsection{Natural Organic Matter (NOM) Characterization}

\subsubsection{Specific Ultraviolet Absorbance (SUVA)}

As seen above, the idea of SUVA has been proposed as a working index of NOM nature and coagulation performance for eliminating NOM removal [1] [2]. Table 9 lists the usually adopted relationships between SUVA, NOM composition, UV absorbance, coagulation and potential TOC removal. Evaluating SUVA is broadly utilized to estimate NOM type since it is simple and inexpensive to assess and is an excellent index of alterations in source water quality [2] [135] [137]. As an illustration, investigators [178] followed DOC and $\mathrm{UV}_{254}$ for the White River (Muncie, Indiana) on a daily basis for 22 months. During this time, SUVA varied from 1.40 to $10.51 \mathrm{~L} / \mathrm{mg} \cdot \mathrm{m}$. Lower levels were related to periods of low runoff and high algal activity (i.e., hydrophilic, autochthonous NOM); however, high levels were attributed to snowmelt and storm runoff. During a typical rainfall event, SUVA augmented from 2.6 to $4.5 \mathrm{~L} / \mathrm{mg} \cdot \mathrm{m}$ during $12 \mathrm{~h}$, showing that hydrophobic, allochthonous NOM was being flushed into the source from the terrestrial watershed. Researchers [184] discussed 18 months of surface water data from the U.S. Environmental Protection Agency (U.S. EPA) and discovered an evident relationship between SUVA, source water properties, and the coagulation performance for eliminating organic carbon [1]. 
Table 9. Link between SUVA and potential TOC elimination [1].

\begin{tabular}{|c|c|c|c|c|}
\hline $\begin{array}{c}\text { SUVA } \\
(\mathrm{L} / \mathrm{mg} \cdot \mathrm{m})\end{array}$ & $\begin{array}{c}\text { NOM } \\
\text { composition }\end{array}$ & $\begin{array}{c}\text { UV } \\
\text { absorbance }\end{array}$ & Coagulation & $\begin{array}{c}\text { Potential } \\
\text { TOC removal }\end{array}$ \\
\hline$<2$ & $\begin{array}{l}\text { Mostly hydrophilic* } \\
\text { and low molecular } \\
\text { weight compounds }\end{array}$ & Low & $\begin{array}{c}\text { NOM has little } \\
\text { impact on } \\
\text { coagulant injection } \\
\text { (i.e., mainly } \\
\text { non-coagulable NOM) }\end{array}$ & $\begin{array}{c}0 \%-40 \% \text {; } \\
\text { higher end for } \\
\text { waters with } \\
\text { high TOC }\end{array}$ \\
\hline $2-4$ & $\begin{array}{l}\text { Mixture of hydrophilic } \\
\text { and hydrophobic } \\
\text { compounds; mixture } \\
\text { of molecular weights }\end{array}$ & Medium & $\begin{array}{l}\text { NOM impacts } \\
\text { coagulant } \\
\text { injection }\end{array}$ & $\begin{array}{c}40 \%-60 \% \text {; } \\
\text { higher end for } \\
\text { waters with } \\
\text { high TOC }\end{array}$ \\
\hline$>4$ & $\begin{array}{l}\text { Mostly hydrophobic } \\
\text { and high molecular } \\
\text { weight compounds }\end{array}$ & High & $\begin{array}{l}\text { NOM controls } \\
\text { coagulant } \\
\text { injection }\end{array}$ & $\begin{array}{c}60 \%-80 \% ; \\
\text { higher end for } \\
\text { waters with } \\
\text { high TOC }\end{array}$ \\
\hline
\end{tabular}

"The hydrophilic neutral fraction could possess an elevated SUVA that can mislead water treatment designers regarding the potential for organic carbon removal utilizing coagulation.

Broadly, elevated SUVA sources $(>4 \mathrm{~L} / \mathrm{mg} \cdot \mathrm{m})$ possess NOM that is amenable to coagulation [2]. Nevertheless, the hydrophilic neutral fraction could possess an elevated SUVA that could be misleading with respect to the potential for organic carbon removal employing coagulation [11]. Further, attaining DBP guideline limits will be a function of the raw water NOM level and whether enough quantity of reactive NOM could be eliminated [145]. If the post-coagulation DOC residual stays reactive with respect to DBP generation, additional techniques targeting the elimination of specific NOM portions will be required [1]. Because humic and fulvic acids are big DBP precursors, the appropriate color reduction could be requested to satisfy DBP removal [115]. Low SUVA sources have a tendency to possess NOM that is not amenable to coagulation [1].

\subsubsection{Chemical Consumption}

Following chemical consumption (like coagulant injection, chlorine demand) and determining the particular injection or demand (i.e., $\mathrm{mg} / \mathrm{L}$ per $\mathrm{mg} / \mathrm{L} \mathrm{DOC}$ ) could aid DWTPs to evaluate alterations in NOM quality. For instance, researchers [185] affirmed that the particular coagulant injection lessened when allochthonous NOM inputs augmented. Likewise, scientists [186] confirmed that the hydrophilic base fraction of NOM forms important chlorine demand, as shown in Table 10. Such a portion includes compounds that are biodegradable (like amino acids). Therefore, eliminating such compounds utilizing biological filtration methods could diminish chlorine demand and DBPs [1]. Investigators [187] alerted that DOC and chlorine demand do not correlate to THMs and HAA5 (i.e., monochloroacetic acid, monobromoacetic acid, dichloroacetic acid, dibromoacetic acid and trichloroacetic acid) because of the existence of some compounds that present important chlorine demand but do not form DBPs. On the other hand, scientists [188] established a linear correlation between THMs 
Table 10. Effect on chlorine demand by NOM portions (+, lowest demand; ++++, highest demand) [1].

\begin{tabular}{cc}
\hline Portion & Chlorine demand \\
\hline Hydrophobic & + \\
Hydrophilic-acids and neutrals & ++ \\
Hydrophilic-bases & +++ \\
Colloidal & + \\
\hline
\end{tabular}

and chlorine demand $\left(R^{2}=0.94\right)$. Further, they observed that chlorine demand may be employed to forecast THM levels in the distribution system when NOM oxidation and halogenation processes dominate, compared with other reactions that consume chorine (like oxidation of inorganic species, photolytic and corrosion processes). Care is suggested when evaluating tendencies related to chlorine demand or specific chlorine demand because reactions are possible to change based on seasonal and weather-related effects, the treatment processes in place, and where chlorine is added [1].

\section{Treatment and Distribution System Notices}

The source-to-tap or water safety plan's approach, which involves the accurate choice of the highest quality water source and source water protection, stays an admitted approach to manage risks to drinking water safety [1]. In order to define the most convenient treatment solutions for the full range of water quality conditions, source-specific treatability studies, comprising bench- and/or pilot-scale testing, have to be performed.

Temporal alterations in the level and type of NOM could possess a considerable impact on the choice, design, and application of water treatment processes [47]. Indeed, DWTPs have to merge hazards that are affected by changes in climate (like algal blooms, drought, fire, and flood) into the procedure to maximize the reliability, robustness, and resilience of their systems [1].

\subsection{Selection of Convenient Treatment}

With a view to suitably choice, design, and run DWTPs, a comprehension of the changes in the level and type of NOM is obligatory-for the full range of circumstances faced over the year, for both surface and groundwater sources [47]. To define the most convenient treatment techniques, DWTPs have to understand the following [1]: 1) the origin, occurrence, and fluctuations in NOM;2) interactions with other water constituents (like enhanced reactivity due to bromide); 3) interactions with chemicals injected during treatment (NOM provokes a disinfectant and coagulant demand that should be overcome to guarantee microbiologically safe potable water); 4) interactions with unit processes (NOM fouls adsorbents and membranes) and; 5) effects on distribution system water quality. 


\subsection{Treatment Options}

Numerous treatment solutions are obtainable to eliminate NOM. Optimized coagulation remains the most frequently utilized technique since it is efficient in most implementations [108]. Nevertheless, its applicability has to be cautiously examined on a source-specific basis since coagulation could only retain some NOM parts; the residual parts (those not eliminated by coagulation) can react with disinfectants such that DBP guidelines are not attained [2]. For instance, allochthonous NOM has a tendency to be hydrophobic in nature and is usually amenable to coagulation; however, hydrophilic NOM has a tendency to be harder to remove [11] [178]. De facto, for sources high in hydrophilic neutral NOM, coagulation will be inefficient [1]. Therefore, it is so crucial that jar testing and DBP formation potential testing be realized to define the applicability of optimized coagulation for NOM elimination [29]. Further or mohair treatment solutions involve nanofiltration, ion exchange, granular activated carbon (GAC) or powdered activated carbon (PAC), biological filtration, and oxidation processes [26] [89] [145].

Treatment solutions and their noted performance are widely discussed in the literature [1]. Findings establish that NOM elimination could be very changing. More detailed data concerning treatment is obtainable in several references [2] [91].

\subsubsection{Optimized Coagulation}

Coagulation is a complicated chemical method that could be optimized for both NOM and turbidity removal [108]. Coagulation implicates two essential routes: the first one is composed of charge neutralization and the generation of insoluble precipitates; the second one includes adsorption onto aluminum or ferric hydroxide floc (i.e., sweep coagulation) [8]. Each route is endorsed by some running circumstances linked to $\mathrm{pH}$ and coagulant injection [2]. As $\mathrm{pH}$ augments, NOM becomes increasingly negatively charged; however, coagulant hydrolysis products with lower positive charge prevail. Consequently, at $\mathrm{pH}>7$ a four-fold augmentation in the coagulant dosage is needed to beat NOM's negative charge juxtaposed with that requested at $\mathrm{pH} 5.5$ [1]. Above $\mathrm{pH} 7$, NOM reduction is inferior [2]. Physical parameters (like mixing of the coagulant and mixing circumstances in the flocculator) could touch floc production. Usually, coagulation chemistry dominates the phenomenon [2].

Selecting a coagulant is a function of the properties of the water to be treated. Obtainable coagulant selections (like aluminum- and ferric-based coagulants, inorganic polymer flocculants, organic polyelectrolytes, composite coagulants, and novel coagulants) are examined elsewhere [1]. Several coagulants furnish a broader operational window in matter $\mathrm{pH}$; however, it is remarkable that for all metal coagulants, the $\mathrm{pH}$ of minimum solubility augments as temperature decreases [1]. For alum, optimum performance usually happens at $\mathrm{pH}$ values near to the $\mathrm{pH}$ of minimum solubility (i.e., $6.5-6.7$ at $4^{\circ} \mathrm{C}$ and $6.0-6.2$ at $20^{\circ} \mathrm{C}$ ) [189]. Because the $\mathrm{pH}$ of minimum solubility is bigger at lower temperatures, a 
greater coagulant dosage could be required to beat the more negative charge on NOM with the lower positive charge on coagulant hydrolysis products, as mentioned previously. Rigorous $\mathrm{pH}$ control is needed for optimum coagulation; indeed, $\mathrm{pH}$ has to be maintained constant from coagulant introduction to after filtration to efficiently retain floc particles. Even a small $\mathrm{pH}$ alteration could liberate NOM that was already combined into flocs [2]. Jar testing remains requested to optimize coagulant choice [27].

Moreover, NOM dictates the size, structure, and strength of the flocs, controlling both the extent and the rate of the clarification or filtration processes [155]. Numerous investigations have established that low-density NOM flocs are more susceptible to flotation than to sedimentation [1].

The charge-driven type of NOM coagulation implies that electrophoretic monitoring is suitable [7]. In any other way, engineers are not well informed of coagulant under-dosing until spikes in settled water or filter effluent turbidity are detected [1] [145]. If possible, the raw water has to be constantly watched to optimize the coagulant injection [145] [160]. Online watching instruments for NOM comprise TOC, DOC, UV absorbance, and COD; for particle destabilization, they involve zeta potential or streaming current [18]. Maximum NOM eliminations have been reached when the coagulant particle charge is near neutral as detected by zeta potential or streaming current [18]. Negligence to regulate the coagulant injection following a variation in NOM could participate in suboptimal coagulation circumstances and a diminution in pathogen log removal's capacity [2] [29].

Table 11 sums the TOC compliance monitoring data published by the U.S. EPA [190] as part of its third Six-Year Review. The data report the TOC elimination (in percent) obtained at traditional surface DWTPs as a function of the influent water quality matrix established by the Disinfectants/DBP Rule. As a rule, the U.S. EPA affirmed that regulated DWTPs are reaching higher reductions than mandated, even if several DWTPs have not been apt to attain reduction requirements. The report warned that the data analysis could not decide which DWTPs are permitted to determine alternative performance criteria or which may have treated water TOC less than $2 \mathrm{mg} / \mathrm{L}$ [1] [190].

Table 11. TOC eliminations noted from U.S. EPA compliance monitoring data (2006-2011) [1] [190].

\begin{tabular}{|c|c|c|c|}
\hline \multirow{2}{*}{$\begin{array}{l}\text { Influent TOC } \\
(\mathrm{mg} / \mathrm{L})\end{array}$} & \multicolumn{3}{|c|}{ Influent alkalinity $\left(\mathrm{mg} / \mathrm{L} \mathrm{CaCO}_{3}\right)$} \\
\hline & $0-60 \mathrm{mg} / \mathrm{L}$ & $>60-120 \mathrm{mg} / \mathrm{L}$ & $>120 \mathrm{mg} / \mathrm{L}$ \\
\hline \multirow{2}{*}{$>2-4$} & Mean $^{\mathrm{a}} 41.7 \%$ & Mean 35.2\% & Mean $30.4 \%$ \\
\hline & Median $^{\mathrm{b}} 41.6 \%$ & Median 35.1\% & Median $30.1 \%$ \\
\hline \multirow{2}{*}{$>4-8$} & Mean $54.7 \%$ & Mean $46.8 \%$ & Mean $44.1 \%$ \\
\hline & Median 54.3\% & Median 46.3\% & Median $43.9 \%$ \\
\hline \multirow{2}{*}{$>8$} & Mean $66.2 \%$ & Mean $46.3 \%$ & Mean $46.9 \%$ \\
\hline & Median $66.4 \%$ & Median $44.2 \%$ & Median $47.8 \%$ \\
\hline
\end{tabular}

${ }^{\mathrm{a} M e a n}$ TOC removal; ${ }^{\mathrm{b}}$ Median TOC removal. 
More details may be found elsewhere [1] [2].

\subsubsection{Membrane Filtration}

Presently, four sorts of pressure-driven membranes are utilized in potable water treatment: microfiltration (MF), ultrafiltration (UF), nanofiltration (NF) and reverse osmosis (RO) [105]. Usually, membranes are categorized by the kind of substances they retain, working pressure, and pore size or molecular weight and cutoff (MWCO) [102]. MF and UF are referred to as low-pressure membranes and are utilized for particle/pathogen removal. The preponderant elimination route is straining or size exclusion. NF and RO are referred to as high-pressure membranes and are employed for retaining NOM and inorganics (like sodium, chloride, calcium, magnesium) [56] [106]. The preponderant reduction route is dissimilarities in the solubility or diffusivity [1] [123].

The size distribution of NOM changes between sources; however, commonly, over $50 \%$ of NOM molecules possess a molecular weight of $<1 \mathrm{kDa}$ and $80 \%$ possess a molecular weight of $<10 \mathrm{kDa}$ [1]. Thus, a tight NF membrane is needed to retain the majority of DBP precursors, as shown in Figure 2. Researches show that the optimum MWCO for NOM retention is $0.2-0.3 \mathrm{kDa}[1]$.

Figure 2 depicts that MF membranes could not retain any NOM parts other than biopolymers. UF membranes can retain some NOM, as illustrated in Figure 2; however, DBP formation potential could not reduce suitably. For instance, researchers [1] mentioned a global DOC retention of $66 \%$ for full-scale UF membranes (absolute pore size $=0.01 \mu \mathrm{m}$ ). THM and HAA formation potentials diminished by $54 \%$ and $77 \%$, respectively; however, both of them stayed elevated at $200 \mu \mathrm{g} / \mathrm{L}$ and $80 \mu \mathrm{g} / \mathrm{L}$, respectively (test conditions: chlorine $1.0 \pm 0.4$ $\mathrm{mg} / \mathrm{L}$ at room temperature for $24 \mathrm{~h}$ ). Scientists [1] obtained color retentions of $>85 \%$ for 27 full-scale NF membrane plants in Norway (raw water's color $=35$ $50 \mathrm{mg} \mathrm{Pt} / \mathrm{L} ; \mathrm{MWCO}=1-2 \mathrm{kDa}$ ).

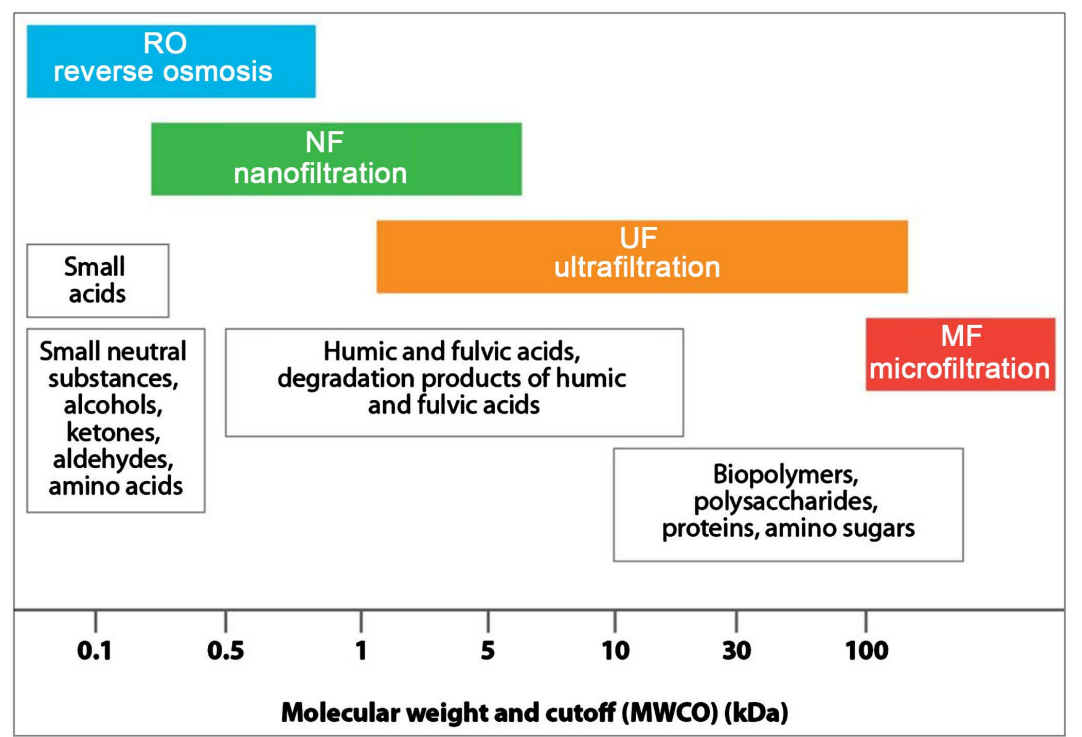

Figure 2. Natural organic matter (NOM) parts retained by membrane processes [1]. 


\subsubsection{Activated Carbon}

Activated carbon is an absorbent material that furnishes a surface on which ions or molecules in the raw water could concentrate [1]. It could be used in two fashions: slurry implementations employing PAC or fixed bed reactors with GAC [177]. The reduction routes implicate adsorption of DOM onto PAC or GAC, as well as biodecomposition of BOM in GAC fixed bed reactors if an active biofilm produces. Researchers [1] observed that biofilms could generate in GAC macropores even in the existence of chlorine.

The first application of PAC and GAC in water treatment is to retain micropollutants as well as taste- and odor-causing substances [1]. Employing PAC presents the merit of furnishing virgin carbon when needed (such as during the taste and odor season). GAC fixed bed devices are run identically to traditional rapid rate filters; thus, the GAC features (like type, particle size, reactivation technique) and running circumstances (such as filter velocity, empty bed contact time, backwashing regime, filter run time) touch their efficacy.

The huge specific surface area and well-developed porous structure of GAC could give high sorption capacity for organic compounds [1]. Nevertheless, GAC has not been largely utilized as a first NOM control strategy since the adsorption capacity of GAC has a tendency to be rapidly depleted (in the order of months) and regeneration could be expensive [1]. As an illustration, the U.S. EPA [190] mentions a 120-day reactivation frequency for systems with TOC of $<6 \mathrm{mg} / \mathrm{L}$ utilizing an empty bed contact time of $10 \mathrm{~min}$. Eliminating high molecular weight hydrophobic NOM by traditional treatment techniques could greatly elevate the working life of GAC [191]. Further, once the adsorption capacity is depleted, GAC could persist to retain NOM via the biodegradation route, although at lower efficacies [1].

Consequently, combining PAC or GAC as a supplementary technique could ameliorate NOM elimination [177]. For PAC, the dose and contact time are fundamental parameters. Findings for two full-scale traditional DWTPs (both utilizing alum coagulation) are mentioned in the literature [1]. In the first one, a PAC dosage of $150 \mathrm{mg} / \mathrm{L}$ ameliorated DOC reduction by $20 \%$ and THM precursors by $80 \%$ [192]. In the last one, a PAC dosage of $11 \mathrm{mg} / \mathrm{L}$ increased DOC reduction by $7 \%$ but attained no amelioration in the elimination of THM precursors [1]. Jar testing is advised to optimize the PAC sort, dose, and contact time. For GAC, investigations show that the pore volume has to be in a size range that matches the source-specific NOM for GAC to be efficient [191]. As mentioned by scientists [191], the surface area and total pore volume are not sufficient criteria for choosing a GAC for NOM reduction, since such factors do not give data concerning the accessible pore region. Karanfil et al. [191] proposed that DWTPs demand detailed data concerning the pore size distribution and the $\mathrm{pH}$ of the point of zero charge for candidate GACs. Rapid small-scale column trials have to be performed to juxtapose the efficiency of alternative GACs, especially for low SUVA sources [191]. Further, the abrasion of GAC particles has to be taken into account, because abrasion could conduct to the lack of GAC material 
and stratification inside the bed, both of which are unwanted [1].

DWTPs that employ activated carbon for eliminating pesticides or different trace contaminants have to be conscious that NOM competes for adsorption sites and could reduce technique effectiveness. Pretreatment could be needed for reducing NOM, to guarantee that the technology stays economical for its wanted aim [1].

\subsubsection{Biological Treatment}

Biological treatment focuses on eliminating the $\mathrm{BOM}$ portion that promotes biofilm growth in the distribution system and augments chlorine demand [1]. Thus, the performance of biological treatment is a function of the quantity of BOM that is existing in the water, the microbial community consuming the BOM, and the temperature [54] [104]. Recalcitrant or refractory NOM is improbable to be retained by biological techniques unless it is oxidized to convert it into BOM. As a rule, biological treatment ameliorates the biological stability of the water and reduces DBP levels, as well as tastes and odors [1].

The principal biological treatment techniques for potable water involve riverbank filtration, rapid granular media filtration without the maintenance of a disinfectant residual across the bed, and slow sand filtration [1].

More details may be found elsewhere [1].

\subsubsection{Oxidation Processes}

Oxidation processes comprise ozone [90], chlorine dioxide [4] [77], and advanced oxidation processes (AOPs) like ozone/UV [26], ozone $/ \mathrm{H}_{2} \mathrm{O}_{2}$ [84], $\mathrm{UV} / \mathrm{H}_{2} \mathrm{O}_{2}$ [86] [101], and Fenton's reaction [78] [89]. Following usual water treatment cases, oxidation processes convert the type of organics rather than eliminate bulk NOM [78] [89]. Therefore, oxidation processes are commonly utilized for killing pathogens, taste and odor control, and decomposition of target organic pollutants. Further, $\mathrm{O}_{3}$ and $\mathrm{ClO}_{2}$ have a tendency to force NOM less responsive with $\mathrm{Cl}_{2}$, which usually leads to reductions of THMs and tri-HAAs; nevertheless, several DBPs could augment like halonitromethanes and haloketones [1]. Ostensibly, AOPs could eliminate a set of NOM; however, they could as well augment the generation of DBPs and dichloroacetic acid (DCAA) especially [193] [194] [195]. Dissimilarities between DCAA and trichloroacetic acid (TCAA) generation were affirmed [1]. In situations designated by negative values, an elevation in DBPs happened because of treatment. Therefore, researchers [1] suggested an accurate estimation of oxidation processes when they are applied for DBP control. Because oxidative processes may lead to the removal of numerous DBPs while augmenting others, mitigative precautions have a tendency to concentrate primarily on reducing DBP production by maximizing NOM elimination [177]. Consequently, employing mohair disinfectants to decrease DBP generation has to be adopted carefully [5] [10] [38].

DWTPs have to be conscious that all oxidants, comprising $\mathrm{Cl}_{2}$, form biodegradable products upon reaction with NOM [4] [44] [77]. Therefore, biologically 
active filtration could be needed to stabilize treated water. Further, DWTPs have to be up to date that all oxidants decrease UV absorbance, which influences SUVA without a related diminution in the NOM level. Consequently, it remains crucial to adopt suitable sampling sites when measuring UV absorbance to determine SUVA [1].

\subsection{Distribution System}

The BOM (biodegradable part of NOM) influences distribution system water quality via furnishing a source of nutrients that participates in bacterial regrowth and biofilm development. Biofilms could give a habitat for the survival of pathogens of fecal origin that may have passed across drinking water treatment barriers. Opportunistic premise plumbing pathogens (OPPPs) like Legionella and non-tuberculous mycobacteria (e.g., Mycobacterium avium, Mycobacterium intracellulare) are as frequently observed in biofilms of piped drinking water supplies [1]. The chance for the multiplication of OPPPs in the distribution system and plumbing system biofilms is of augmenting worry to the DWTPs. For instance, in the United States, the most frequently noted reason of eruptions related to potable water is Legionella linked to building plumbing systems (largely in hospitals or health care facilities that fall outside the jurisdiction of water utilities) [1].

More details may be found elsewhere [1].

\section{Conclusions}

From this review, the following observations and conclusions arose:

1) DWTPs have to compile water quality data to regulate their water treatment techniques, satisfy regulatory requirements associated with DBPs, lead and copper, as well as lessen biofilm generation. Site-specific situations and treatment targets affect monitoring requirements, comprising, but are not limited to parameter selection, analysis method, and frequency. The monitoring frequency is frequently founded on source variability and/or the critical nature of treatment technology. Highly variable water sources and critical processes have to, therefore, be controlled on a more frequent basis [1].

2) Raw water control has to be performed to distinguish the source and better grasp the circumstances that conduct to alterations in the levels and/or type of NOM (e.g., precipitation/snowmelt events, algal blooms, drought, fire), and the parameters that ameliorate the reactivity of NOM to produce DBPs (e.g., reaction parameters, water age, inorganic compounds such as ammonia, bromide, iodide, and sulfur). Continuing running control and treatment regulation will assist to guarantee that DWTPs conveniently eliminate NOM to satisfy linked water quality aims concerning microbial dangers, DBPs, biological stability, and corrosion control. The compiled data have to be examined to evaluate the following [1]:

- If, and how, source water quality is varying (like true color, UV absorbance, 
DOC, SUVA);

- If a correlation exists between raw water DOC and other surrogates are utilized to quantify NOM level (like true color, UV absorbance);

- How NOM is affecting water treatment techniques (like chemical utilization and specific chemical injection/demand) and if control restrictions have to be defined;

- How the treatment is influencing NOM (such as remaining NOM level, alteration in SUVA, specific DBP yields, specific color) and if control restrictions have to be defined;

- Distribution system effects (like DBP levels, lead/copper levels);

- Biological stability (like variability in disinfectant residual, biofilm formation rate, modifications in corrosion rates); and

- If a correlation exists between treated water NOM surrogates (such as DOC, true color, UV absorbance, COD) and distribution system water quality (like DBPs, specific DBP yields, lead, copper, biological stability).

3) A permanent amelioration action has to be implemented to guarantee water treatment is regulated to attain water quality targets and increase public health safeguards for the full range of water quality circumstances. Treated water quality objectives will be source- and system-specific for the next causes [1]:

- Numerous sources could possess a higher specific DBP yield (like $\mu \mathrm{g}$ $\mathrm{DBP} / \mathrm{mg}$ DOC) than other sources. This could be related to source-specific dissimilarities in NOM type (such as some NOM portions produce more DBPs than others do) or the occurrence of inorganic compounds that augment DBP formation rates (like ammonia, bromide, iodide, and sulfur). Sources with higher specific DBP yields are classified as more "reactive".

- Some systems have extensive distribution systems. A distribution system with a residence time of 7 days and a temperature of $>15^{\circ} \mathrm{C}$ will need a different level of NOM removal to meet DBP guidelines than one with a residence time of 3 days and a temperature of $<15^{\circ} \mathrm{C}$.

4) For more responsive sources and extensive distribution systems, water has to be treated to more strict requirements, since there is a bigger probability for DBP generation. Less responsive sources have more flexibility concerning upper control limits for most of the parameters, with the following exceptions [1]:

- COD: as COD quantifies oxidizable organic matter, a highly responsive source with $2 \mathrm{mg} / \mathrm{L}$ TOC and a less responsive source with $4 \mathrm{mg} / \mathrm{L}$ TOC could possess comparable COD levels.

- DOC for biological stability: a DOC of $<1.8 \mathrm{mg} / \mathrm{L}$ is proposed to minimize the biofilm generation rate and disinfectant variability regardless of source water quality or secondary disinfectant used for residual control (free chlorine).

\section{Acknowledgements}

The Research Deanship of University of Ha'il, Saudi Arabia, through the Project RG-19 1190, has funded this research. 


\section{Conflicts of Interest}

The author declares no conflicts of interest regarding the publication of this paper.

\section{References}

[1] Health Canada (2020) Guidance on Natural Organic Matter in Drinking Water. Water and Air Quality Bureau, Healthy Environments and Consumer Safety Branch, Health Canada, Ottawa. (Catalogue No. H144-67/2020E-PDF)

[2] Ghernaout, D., Ghernaout, B. and Kellil, A. (2009) Natural Organic Matter Removal and Enhanced Coagulation as a Link between Coagulation and Electrocoagulation. Desalination and Water Treatment, 2, 203-222.

https://doi.org/10.5004/dwt.2009.116

[3] Ghernaout, B., Ghernaout, D. and Saiba, A. (2010) Algae and Cyanotoxins Removal by Coagulation/Flocculation: A Review. Desalination and Water Treatment, 20, 133-143. https://doi.org/10.5004/dwt.2010.1202

[4] Ghernaout, D., Naceur, M.W. and Aouabed, A. (2011) On the Dependence of Chlorine By-Products Generated Species Formation of the Electrode Material and Applied Charge during Electrochemical Water Treatment. Desalination, 270, 9-22. https://doi.org/10.1016/j.desal.2011.01.010

[5] Ghernaout, D., Ghernaout, B. and Naceur, M.W. (2011) Embodying the Chemical Water Treatment in the Green Chemistry-A Review. Desalination, 271, 1-10. https://doi.org/10.1016/j.desal.2011.01.032

[6] Ghernaout, D. and Naceur, M.W. (2011) Ferrate(VI): In Situ Generation and Water Treatment-A Review. Desalination, and Water Treatment, 30, 319-332. https://doi.org/10.5004/dwt.2011.2217

[7] Ghernaout, D., Naceur, M.W. and Ghernaout, B. (2011) A Review of Electrocoagulation as a Promising Coagulation Process for Improved Organic and Inorganic Matters Removal by Electrophoresis and Electroflotation. Desalination, and Water Treatment, 28, 287-320. https://doi.org/10.5004/dwt.2011.1493

[8] Ghernaout, D. and Ghernaout, B. (2012) Sweep Flocculation as a Second Form of Charge Neutralisation-A Review. Desalination, and Water Treatment, 44, 15-28. https://doi.org/10.1080/19443994.2012.691699

[9] Ghernaout, D. and Ghernaout, B. (2012) On the Concept of the Future Drinking Water Treatment Plant: Algae Harvesting from the Algal Biomass for Biodiesel Production-A Review. Desalination, and Water Treatment, 49, 1-18. https://doi.org/10.1080/19443994.2012.708191

[10] Ghernaout, D. (2013) The Best Available Technology of Water/Wastewater Treatment and Seawater Desalination: Simulation of the Open Sky Seawater Distillation. Green and Sustainable Chemistry, 3, 68-88. https://doi.org/10.4236/gsc.2013.32012

[11] Ghernaout, D. (2014) The Hydrophilic/Hydrophobic Ratio vs. Dissolved Organics Removal by Coagulation-A Review. Journal of King Saud University-Science, 26, 169-180. https://doi.org/10.1016/j.jksus.2013.09.005

[12] Ghernaout, D., Moulay, S., Ait Messaoudene, N., Aichouni, M., Naceur, M.W. and Boucherit, A. (2014) Coagulation and Chlorination of NOM and Algae in Water Treatment: A Review. International Journal of Environmental Monitoring and Analysis, 2, 23-34. https://doi.org/10.11648/j.ijema.s.2014020601.14

[13] Ghernaout, D., Irki, S. and Boucherit, A. (2014) Removal of $\mathrm{Cu}^{2+}$ and $\mathrm{Cd}^{2+}$, and Humic Acid and Phenol by Electrocoagulation Using Iron Electrodes. Desalination, 
and Water Treatment, 52, 3256-3270.

https://doi.org/10.1080/19443994.2013.852484

[14] Ghernaout, D., Al-Ghonamy, A.I., Naceur, M.W., Ait Messaoudene, N. and Aichouni, M. (2014) Influence of Operating Parameters on Electrocoagulation of C.I. Disperse Yellow 3. Journal of Electrochemical Science and Engineering, 4, 271-283. https://doi.org/10.5599/jese.2014.0065

[15] Ghernaout, D., Al-Ghonamy, A.I., Irki, S., Grini, A., Naceur, M.W., Ait Messaoudene, N. and Aichouni, M. (2014) Decolourization of Bromophenol Blue by Electrocoagulation Process. Trends in Chemical Engineering, 15, 29-39.

[16] Ghernaout, D., Benblidia, C. and Khemici, F. (2015) Microalgae Removal from Ghrib Dam (Ain Defla, Algeria) Water by Electroflotation Using Stainless Steel Electrodes. Desalination, and Water Treatment, 54, 3328-3337. https://doi.org/10.1080/19443994.2014.907749

[17] Ghernaout, D., Al-Ghonamy, A.I., Boucherit, A., Ghernaout, B., Naceur, M.W., Ait Messaoudene, N., Aichouni, M., Mahjoubi, A.A. and Elboughdiri, N.A. (2015) Brownian Motion and Coagulation Process. American Journal of Environmental Protection, 4, 1-15.

[18] Ghernaout, D., Al-Ghonamy, A.I., Naceur, M.W., Boucherit, A., Messaoudene, N.A., Aichouni, M., Mahjoubi, A.A. and Elboughdiri, N.A. (2015) Controlling Coagulation Process: From Zeta Potential to Streaming Potential. American Journal of Environmental Protection, 4, 16-27. https://doi.org/10.11648/j.ajeps.s.2015040501.12

[19] Ghernaout, D., Al-Ghonamy, A.I., Ait Messaoudene, N., Aichouni, M., Naceur, M.W., Benchelighem, F.Z. and Boucherit, A. (2015) Electrocoagulation of Direct Brown 2 (DB) and BF Cibacete Blue (CB) Using Aluminum Electrodes. Separation Science and Technology, 50, 1413-1420. https://doi.org/10.1080/01496395.2014.982763

[20] Ghernaout, D., Ghernaout, B., Saiba, A., Boucherit, A. and Kellil, A. (2009) Removal of Humic Acids by Continuous Electromagnetic Treatment Followed by Electrocoagulation in Batch Using Aluminium Electrodes. Desalination, 239, 295-308. https://doi.org/10.1016/j.desal.2008.04.001

[21] Ghernaout, D., Ghernaout, B., Boucherit, A., Naceur, M.W., Khelifa, A. and Kellil, A. (2009) Study on Mechanism of Electrocoagulation with Iron Electrodes in Idealised Conditions and Electrocoagulation of Humic Acids Solution in Batch Using Aluminium Electrodes. Desalination, and Water Treatment, 8, 91-99. https://doi.org/10.5004/dwt.2009.668

[22] Saiba, A., Kourdali, S., Ghernaout, B. and Ghernaout, D. (2010) In Desalination, from 1987 to 2009, the Birth of a New Seawater Pretreatment Process: Electrocoagulation-An Overview. Desalination, and Water Treatment, 16, 201-217. https://doi.org/10.5004/dwt.2010.1094

[23] Belhout, D., Ghernaout, D., Djezzar-Douakh, S. and Kellil, A. (2010) Electrocoagulation of a Raw Water of Ghrib Dam (Algeria) in Batch Using Iron Electrodes. Desalination, and Water Treatment, 16, 1-9. https://doi.org/10.5004/dwt.2010.1081

[24] Ghernaout, D., Mariche, A., Ghernaout, B. and Kellil, A. (2010) Electromagnetic Treatment-Bi-Electrocoagulation of Humic Acid in Continuous Mode Using Response Surface Method for Its Optimization and Application on Two Surface Waters. Desalination, and Water Treatment, 22, 311-329. https://doi.org/10.5004/dwt.2010.1120

[25] Ghernaout, D. and Ghernaout, B. (2011) On the Controversial Effect of Sodium 
Sulphate as Supporting Electrolyte on Electrocoagulation Process: A Review. Desalination, and Water Treatment, 27, 243-254. https://doi.org/10.5004/dwt.2011.1983

[26] Ghernaout, D. (2013) Advanced Oxidation Phenomena in Electrocoagulation Process: A Myth or a Reality? Desalination and Water Treatment, 51, 7536-7554. https://doi.org/10.1080/19443994.2013.792520

[27] Ghernaout, D. and Boucherit, A. (2015) Review of Coagulation's Rapid Mixing for NOM Removal. Journal of Research \& Developments in Chemistry, 2015, Article ID: 926518. https://doi.org/10.5171/2015.926518

[28] Boucherit, A., Moulay, S., Ghernaout, D., Al-Ghonamy, A.I., Ghernaout, B., Naceur, M.W., Ait Messaoudene, N., Aichouni, M., Mahjoubi, A.A. and Elboughdiri, N.A. (2015) New Trends in Disinfection By-Products Formation upon Water Treatment. Journal of Research \& Developments in Chemistry, 2015, Article ID: 628833. https://doi.org/10.5171/2015.628833

[29] Ghernaout, D., Badis, A., Braikia, G., Matâam, N., Fekhar, M., Ghernaout, B. and Boucherit, A. (2017) Enhanced Coagulation for Algae Removal in a Typical Algeria Water Treatment Plant. Environmental Engineering and Management Journal, 16, 2303-2315. https://doi.org/10.30638/eemj.2017.238

[30] Irki, S., Ghernaout, D. and Naceur, M.W. (2017) Decolourization of Methyl Orange (MO) by Electrocoagulation (EC) Using Iron Electrodes under a Magnetic Field (MF). Desalination, and Water Treatment, 79, 368-377. https://doi.org/10.5004/dwt.2017.20797

[31] Ghernaout, D. (2017) Environmental Principles in the Holy Koran and the Sayings of the Prophet Muhammad. American Journal of Environmental Protection, 6, 75-79. https://doi.org/10.11648/j.ajep.20170603.13

[32] Ghernaout, D. (2017) Microorganisms' Electrochemical Disinfection Phenomena. EC Microbiology, 9, 160-169.

[33] Ghernaout, D. (2017) Water Treatment Chlorination: An Updated Mechanistic Insight Review. Chemistry Research Journal, 2, 125-138.

[34] Ghernaout, D. (2017) Water Reuse (WR): The Ultimate and Vital Solution for Water Supply Issues. International Journal of Sustainable Development Research, 3, 36-46. https://doi.org/10.11648/j.ijsdr.20170304.12

[35] Ghernaout, D. (2018) Increasing Trends towards Drinking Water Reclamation from Treated Wastewater. World Journal of Applied Chemistry, 3, 1-9. https://doi.org/10.11648/j.wjac.20180301.11

[36] Ghernaout, D. (2018) Magnetic Field Generation in the Water Treatment Perspectives: An Overview. International Journal of Advances in Applied Sciences, 5, 193-203. https://doi.org/10.21833/ijaas.2018.01.025

[37] Ghernaout, D. (2017) Entropy in the Brownian Motion (BM) and Coagulation Background. Colloid and Surface Science, 2, 143-161.

[38] Ghernaout, D. (2018) Disinfection and DBPs Removal in Drinking Water Treatment: A Perspective for a Green Technology. International Journal of Advances in Applied Sciences, 5, 108-117. https://doi.org/10.21833/ijaas.2018.02.018

[39] Ghernaout, D., Aichouni, M. and Alghamdi, A. (2018) Applying Big Data (BD) in Water Treatment Industry: A New Era of Advance. International Journal of Advances in Applied Sciences, 5, 89-97. https://doi.org/10.21833/ijaas.2018.03.013

[40] Ghernaout, D. (2008) Élimination des substances humiques et des germes indicateurs de contamination bactériologique par électrocoagulation assistée d'un traitement magnétique de l'eau. Ph.D. Thesis, University of Blida, Algeria. 
[41] Ghernaout, D., Simoussa, A., Alghamdi, A., Ghernaout, B., Elboughdiri, N., Mahjoubi, A., Aichouni, M. and El-Wakil, A.E.A. (2018) Combining Lime Softening with Alum Coagulation for Hard Ghrib Dam Water Conventional Treatment. International Journal of Advances in Applied Sciences, 5, 61-70. https://doi.org/10.21833/ijaas.2018.05.008

[42] Ghernaout, D., Laribi, C., Alghamdi, A., Ghernaout, B., Ait Messaoudene, N. and Aichouni, M. (2018) Decolorization of BF Cibacete Blue (CB) and Red Solophenyle 3BL (RS) Using Aluminum Sulfate and Ferric Chloride. World Journal of Applied Chemistry, 3, 32-40. https://doi.org/10.11648/j.wjac.20180302.11

[43] Djezzar, S., Ghernaout, D., Cherifi, H., Alghamdi, A., Ghernaout, B. and Aichouni, M. (2018) Conventional, Enhanced, and Alkaline Coagulation for Hard Ghrib Dam (Algeria) Water. World Journal of Applied Chemistry, 3, 41-55. https://doi.org/10.11648/j.wjac.20180302.12

[44] Ghernaout, D., Alghamdi, A., Aichouni, M. and Touahmia, M. (2018) The Lethal Water Tri-Therapy: Chlorine, Alum, and Polyelectrolyte. World Journal of Applied Chemistry, 3, 65-71. https://doi.org/10.11648/j.wjac.20180302.14

[45] Irki, S., Ghernaout, D., Naceur, M.W., Alghamdi, A. and Aichouni, M. (2018) Decolorization of Methyl Orange (MO) by Electrocoagulation (EC) Using Iron Electrodes under a Magnetic Field (MF). II. Effect of Connection Mode. World Journal of Applied Chemistry, 3, 56-64. https://doi.org/10.11648/j.wjac.20180302.13

[46] Irki, S., Ghernaout, D., Naceur, M.W., Alghamdi, A. and Aichouni, M. (2018) Decolorizing Methyl Orange by Fe-Electrocoagulation Process-A Mechanistic Insight. International Journal of Environmental Chemistry, 2, 18-28. https://doi.org/10.11648/j.ijec.20180201.14

[47] Alshammari, Y., Ghernaout, D., Aichouni, M. and Touahmia, M. (2018) Improving Operational Procedures in Riyadh's (Saudi Arabia) Water Treatment Plants Using Quality Tools. Applied Engineering, 2, 60-71.

[48] Ghernaout, D., Touahmia, M. and Aichouni, M. (2019) Disinfecting Water: Electrocoagulation as an Efficient Process. Applied Engineering, 3, 1-12.

[49] Ghernaout, D., Aichouni, M. and Touahmia, M. (2019) Mechanistic Insight into Disinfection by Electrocoagulation-A Review. Desalination, and Water Treatment, 141, 68-81. https://doi.org/10.5004/dwt.2019.23457

[50] Ghernaout, D., Alghamdi, A. and Ghernaout, B. (2019) Electrocoagulation Process: A Mechanistic Review at the Dawn of Its Modeling. Journal of Environmental Science and Allied Research, 2, 51-67. https://doi.org/10.29199/2637-7063/ESAR-201019

[51] Ghernaout, D., Alghamdi, A. and Ghernaout, B. (2019) Microorganisms' Killing: Chemical Disinfection vs. Electrodisinfection. Applied Engineering, 3, 13-19.

[52] Ghernaout, D. (2019) Greening Electrocoagulation Process for Disinfecting Water. Applied Engineering, 3, 27-31.

[53] Ghernaout, D. (2019) Aeration Process for Removing Radon from Drinking Water-A Review. Applied Engineering, 3, 32-45.

[54] Ghernaout, D. (2019) Reviviscence of Biological Wastewater Treatment-A Review. Applied Engineering, 3, 46-55.

[55] Kellali, Y. and Ghernaout, D. (2019) Physicochemical and Algal Study of Three Dams (Algeria) and Removal of Microalgae by Enhanced Coagulation. Applied Engineering, 3, 56-64.

[56] Ghernaout, D. (2019) Brine Recycling: Towards Membrane Processes as the Best 
Available Technology. Applied Engineering, 3, 71-84.

[57] Ghernaout, D. (2019) Electrocoagulation Process for Microalgal Biotechnology-A Review. Applied Engineering, 3, 85-94.

[58] Ghernaout, D. (2019) Greening Cold Fusion as an Energy Source for Water Treatment Distillation-A Perspective. American Journal of Quantum Chemistry and Molecular Spectroscopy, 3, 1-5.

[59] Ghernaout, D. (2019) Virus Removal by Electrocoagulation and Electrooxidation: New Findings and Future Trends. Journal of Environmental Science and Allied Research, 85-90. https://doi.org/10.29199/2637-7063/ESAR-202024

[60] Ghernaout, D. (2019) Electrocoagulation and Electrooxidation for Disinfecting Water: New Breakthroughs and Implied Mechanisms. Applied Engineering, 3, 125-133.

[61] Cheng, M.-L., Ho, H.-Y., Chiu, D.T.-Y. and Lu, F.-J. (1999) Humic Acid-Mediated Oxidative Damages to Human Erythrocytes: A Possible Mechanism Leading to Anemia in Blackfoot Disease. Free Radical Biology and Medicine, 27, 470-477. https://doi.org/10.1016/S0891-5849(99)00072-6

[62] Tseng, C.-H. (2005) Blackfoot Disease and Arsenic: A Never-Ending Story. Journal of Environmental Science and Health, 23, 55-74. https://doi.org/10.1081/GNC-200051860

[63] Ghernaout, D. and Elboughdiri, N. (2019) Electrocoagulation Process Intensification for Disinfecting Water-A Review. Applied Engineering, 3, 140-147.

[64] Ghernaout, D. and Elboughdiri, N. (2019) Iron Electrocoagulation Process for Disinfecting Water-A Review. Applied Engineering, 3, 154-158.

[65] Ghernaout, D. (2019) Disinfection via Electrocoagulation Process: Implied Mechanisms and Future Tendencies. EC Microbiology, 15, 79-90.

[66] Ghernaout, D., Elboughdiri, N. and Al Arni, S. (2019) Water Reuse (WR): Dares, Restrictions, and Trends. Applied Engineering, 3, 159-170.

[67] Ghernaout, D., Elboughdiri, N. and Ghareba, S. (2019) Drinking Water Reuse: One-Step Closer to Overpassing the "Yuck Factor". Open Access Library Journal, 6, 6: e5895. https://doi.org/10.4236/oalib.1105895

[68] Ghernaout, D. and Elboughdiri, N. (2019) Mechanistic Insight into Disinfection Using Ferrate(VI). Open Access Library Journal, 6, e5946.

[69] Ghernaout, D. and Elboughdiri, N. (2019) Water Disinfection: Ferrate(VI) as the Greenest Chemical-A Review. Applied Engineering, 3, 171-180.

[70] Ghernaout, D. and Elboughdiri, N. (2019) Upgrading Wastewater Treatment Plant to Obtain Drinking Water. Open Access Library Journal, 6, e5959. https://doi.org/10.4236/oalib.1105959

[71] Ghernaout, D., Elboughdiri, N. and Alghamdi, A. (2019) Direct Potable Reuse: The Singapore NEWater Project as a Role Model. Open Access Library Journal, 6, e5980. https://doi.org/10.4236/oalib.1105980

[72] Ghernaout, D. and Elboughdiri, N. (2019) Water Reuse: Emerging Contaminants Elimination-Progress and Trends. Open Access Library Journal, 6, e5981. https://doi.org/10.4236/oalib.1105981

[73] Ghernaout, D. and Elboughdiri, N. (2020) Electrochemical Technology for Wastewater Treatment: Dares and Trends. Open Access Library Journal, 7, e6020.

[74] Ghernaout, D. and Elboughdiri, N. (2020) Magnetic Field Application: An Underappreciated Outstanding Technology. Open Access Library Journal, 7, e6000. 
[75] Ghernaout, D. and Elboughdiri, N. (2020) Antibiotics Resistance in Water Mediums: Background, Facts, and Trends. Applied Engineering, 4, 1-6. https://doi.org/10.4236/oalib.1106374

[76] Ghernaout, D. and Elboughdiri, N. (2020) Removing Antibiotic-Resistant Bacteria (ARB) Carrying Genes (ARGs): Challenges and Future Trends. Open Access Library Journal, 7, e6003. https://doi.org/10.4236/oalib.1106003

[77] Ghernaout, D. and Elboughdiri, N. (2020) Is Not It Time to Stop Using Chlorine for Treating Water? Open Access Library Journal, 7, e6007.

[78] Ghernaout, D., Elboughdiri, N. and Ghareba, S. (2020) Fenton Technology for Wastewater Treatment: Dares and Trends. Open Access Library Journal, 7, e6045. https://doi.org/10.4236/oalib.1106045

[79] Ghernaout, D. and Elboughdiri, N. (2020) Strategies for Reducing Disinfection By-Products Formation during Electrocoagulation. Open Access Library Journal, 7, e6076.

[80] Ghernaout, D. and Elboughdiri, N. (2020) Electrocoagulation Process in the Context of Disinfection Mechanism. Open Access Library Journal, 7, e6083.

[81] Ghernaout, D. and Elboughdiri, N. (2020) On the Treatment Trains for Municipal Wastewater Reuse for Irrigation. Open Access Library Journal, 7, e6088.

[82] Ghernaout, D. and Elboughdiri, N. (2020) Should We Forbid the Consumption of Antibiotics to Stop the Spread of Resistances in Nature? Open Access Library Journal, 7, e6138.

[83] Ghernaout, D. and Elboughdiri, N. (2020) Disinfection By-Products: Presence and Elimination in Drinking Water. Open Access Library Journal, 7, e6140.

[84] Ghernaout, D. and Elboughdiri, N. (2020) Advanced Oxidation Processes for Wastewater Treatment: Facts and Future Trends. Open Access Library Journal, 7, e6139.

[85] Ghernaout, D. and Elboughdiri, N. (2020) Domestic Wastewater Treatment: Difficulties and Reasons, and Prospective Solutions-China as an Example. Open Access Library Journal, 7, e6141.

[86] Ghernaout, D. and Elboughdiri, N. (2020) UV-C/ $/ \mathrm{H}_{2} \mathrm{O}_{2}$ and Sunlight $/ \mathrm{H}_{2} \mathrm{O}_{2}$ in the Core of the Best Available Technologies for Dealing with Present Dares in Domestic Wastewater Reuse. Open Access Library Journal, 7, e6161. https://doi.org/10.4236/oalib.1106161

[87] Ghernaout, D. and Elboughdiri, N. (2020) Controlling Disinfection By-Products Formation in Rainwater: Technologies and Trends. Open Access Library Journal, 7, e6162.

[88] Ghernaout, D., Boudjemline, A. and Elboughdiri, N. (2020) Electrochemical Engineering in the Core of the Dye-Sensitized Solar Cells (DSSCs). Open Access Library Journal, 7, e6178.

[89] Ghernaout, D., Elboughdiri, N., Ghareba, S. and Salih, A. (2020) Electrochemical Advanced Oxidation Processes (EAOPs) for Disinfecting Water-Fresh Perspectives. Open Access Library Journal, 7, e6257. https://doi.org/10.4236/oalib.1106257

[90] Ghernaout, D. and Elboughdiri, N. (2020) Towards Enhancing Ozone Diffusion for Water Disinfection-Short Notes. Open Access Library Journal, 7, e6253. https://doi.org/10.4236/oalib.1106253

[91] Ghernaout, D. and Elboughdiri, N. (2020) Eliminating Cyanobacteria and Controlling Algal Organic Matter-Short Notes. Open Access Library Journal, 7, e6252.

[92] Ghernaout, D., Elboughdiri, N., Ghareba, S. and Salih, A. (2020) Disinfecting Water 
with the Carbon Fiber-Based Flow-through Electrode System (FES): Towards Axial Dispersion and Velocity Profile. Open Access Library Journal, 7, e6238. https://doi.org/10.4236/oalib.1106238

[93] Ghernaout, D., Elboughdiri, N., Ghareba, S. and Salih, A. (2020) Coagulation Process for Removing Algae and Algal Organic Matter-An Overview. Open Access Library Journal, 7, e6272. https://doi.org/10.4236/oalib.1106272

[94] Ghernaout, D. and Elboughdiri, N. (2020) Environmental Engineering for Stopping Viruses Pandemics. Open Access Library Journal, 7, e6299.

[95] Dai, R., Xiong, Y., Ma, Y. and Tang, T. (2020) Algae Removal Performance of UV-Radiation-Enhanced Coagulation for Two Representative Algal Species. Science of the Total Environment, 745, Article ID: 141013.

https://doi.org/10.1016/j.scitotenv.2020.141013

[96] Ghernaout, D. and Elboughdiri, N. (2020) An Insight in Electrocoagulation Process through Current Density Distribution (CDD). Open Access Library Journal, 7, e6142.

[97] Ghernaout, D. and Elboughdiri, N. (2020) Disinfecting Water: Plasma Discharge for Removing Coronaviruses. Open Access Library Journal, 7, e6314.

https://doi.org/10.4236/oalib.1106314

[98] Ghernaout, D., Elboughdiri, N., Alghamdi, A. and Ghernaout, B. (2020) Trends in Decreasing Disinfection By-Products Formation during Electrochemical Technologies. Open Access Library Journal, 7, e6337. https://doi.org/10.4236/oalib.1106337

[99] Ghernaout, D. and Elboughdiri, N. (2020) Foresight Look on the Disinfection By-Products Formation. Open Access Library Journal, 7, e6349.

[100] Ghernaout, D. and Elboughdiri, N. (2020) Solar Treatment in the Core of the New Disinfection Technologies. Chemical Science \& Engineering Research, 2, 6-11.

[101] Ghernaout, D. and Elboughdiri, N. (2020) Vacuum-UV Radiation at $185 \mathrm{~nm}$ for Disinfecting Water. Chemical Science \& Engineering Research, 2, 12-17.

[102] Ghernaout, D., Alshammari, Y., Alghamdi, A., Aichouni, M., Touahmia, M. and Ait Messaoudene, N. (2018) Water Reuse: Extenuating Membrane Fouling in Membrane Processes. International Journal of Environmental Chemistry, 2, 1-12. https://doi.org/10.11648/j.ajche.20180602.12

[103] Ait Messaoudene, N., Naceur, M.W., Ghernaout, D., Alghamdi, A. and Aichouni, M. (2018) On the Validation Perspectives of the Proposed Novel Dimensionless Fouling Index. International Journal of Advances in Applied Sciences, 5, 116-122.

[104] Ghernaout, D. (2020) New Configurations and Techniques for Controlling Membrane Bioreactor (MBR) Fouling. Open Access Library Journal, 7, e6579.

[105] Ghernaout, D. and El-Wakil, A. (2017) Requiring Reverse Osmosis Membranes Modifications-An Overview. American Journal of Chemical Engineering, 5, 81-88. https://doi.org/10.11648/j.ajche.20170504.15

[106] Ghernaout, D. (2017) Reverse Osmosis Process Membranes Modeling-A Historical Overview. Journal of Civil, Construction and Environmental Engineering, 2, $112-122$

[107] Ghernaout, D. (2020) Electric Field (EF) in the Core of the Electrochemical (EC) Disinfection. Open Access Library Journal, 7, e6587.

[108] Ghernaout, D. (2020) Enhanced Coagulation: Promising Findings and Challenges. Open Access Library Journal, 7, e6569.

[109] Ghernaout, D. and Elboughdiri, N. (2020) Dealing with Cyanobacteria and Cyano- 
toxins: Engineering Viewpoints. Open Access Library Journal, 7, e6363.

[110] Ghernaout, D. and Elboughdiri, N. (2020) Disinfection By-Products (DBPs) Control Strategies in Electrodisinfection. Open Access Library Journal, 7, e6396. https://doi.org/10.4236/oalib.1106396

[111] Ghernaout, D., Alshammari, Y. and Alghamdi, A. (2018) Improving Energetically operational Procedures in Wastewater Treatment Plants. International Journal of Advances in Applied Sciences, 5, 64-72. https://doi.org/10.21833/ijaas.2018.09.010

[112] Ghernaout, D. (2020) Water Treatment Challenges towards Viruses Removal. Open Access Library Journal, 7, e6408.

[113] Ghernaout, D. (2018) Electrocoagulation Process: Achievements and Green Perspectives. Colloid and Surface Science, 3, 1-5. https://doi.org/10.11648/j.css.20180301.11

[114] Ghernaout, D., Badis, A., Ghernaout, B. and Kellil, A. (2008) Application of Electrocoagulation in Escherichia coli Culture and Two Surface Waters. Desalination, 219, 118-125. https://doi.org/10.1016/j.desal.2007.05.010

[115] Ghernaout, D. and Elboughdiri, N. (2020) Disinfection By-Products Regulation: Zero ng/L Target. Open Access Library Journal, 7, e6382.

[116] Ghernaout, D., Alghamdi, A., Touahmia, M., Aichouni, M. and Ait Messaoudene, N. (2018) Nanotechnology Phenomena in the Light of the Solar Energy. Journal of Energy, Environmental \& Chemical Engineering, 3, 1-8. https://doi.org/10.11648/j.jeece.20180301.11

[117] Ghernaout, D. and Ghernaout, B. (2020) Controlling COVID-19 Pandemic through Wastewater Monitoring. Open Access Library Journal, 7, e6411. https://doi.org/10.4236/oalib.1106411

[118] Ghernaout, D. and Elboughdiri, N. (2020) On the Other Side of Viruses in the Background of Water Disinfection. Open Access Library Journal, 7, e6374.

[119] Al Arni, S., Amous, J. and Ghernaout, D. (2019) On the Perspective of Applying of a New Method for Wastewater Treatment Technology: Modification of the Third Traditional Stage with Two Units, One by Cultivating Microalgae and Another by Solar Vaporization. International Journal of Environmental Sciences \& Natural Resources, 16, Article ID: 555934. https://doi.org/10.19080/IJESNR.2019.16.555934

[120] Ghernaout, D. and Ghernaout, B. (2010) From Chemical Disinfection to Electrodisinfection: The Obligatory Itinerary? Desalination and Water Treatment, 16, 156-175. https://doi.org/10.5004/dwt.2010.1085

[121] Ghernaout, D. (2020) Charge Neutralization in the Core of Plasma Treatment. Open Access Library Journal, 7, e6434.

[122] Ghernaout, D. and Elboughdiri, N. (2020) Urgent Proposals for Disinfecting Hospital Wastewaters during COVID-19 Pandemic. Open Access Library Journal, 7, e6373. https://doi.org/10.4236/oalib.1106373

[123] Ghernaout, D., El-Wakil, A., Alghamdi, A., Elboughdiri, N. and Mahjoubi, A. (2018) Membrane Post-Synthesis Modifications and How It Came about. International Journal of Advances in Applied Sciences, 5, 60-64. https://doi.org/10.21833/ijaas.2018.02.010

[124] Stevenson, F.J. (1982) Humus Chemistry: Genesis, Composition, Reactions. John Wiley \& Sons, New York.

[125] Thurman, E.M. (1985) Organic Geochemistry of Natural Waters. Kluwer Academic Publishers Group, Dordrecht. https://doi.org/10.1007/978-94-009-5095-5

[126] Bond, T., Goslan, E.H., Parsons, S.A. and Jefferson, B. (2012) A Critical Review of 
Trihalomethane and Haloacetic Acid Formation from Natural Organic Matter Surrogates. Environmental Technology Reviews, 1, 93-113.

https://doi.org/10.1080/09593330.2012.705895

[127] Aiken, G. and Cotsaris, E. (1995) Soil and Hydrology: Their Effect on NOM. Journal of the American Water Works Association, 87, 36-45. https://doi.org/10.1002/j.1551-8833.1995.tb06299.x

[128] Kalbitz, K., Solinger, S., Park, J.-H., Michalzik, B. and Matzner, E. (2000) Controls on the Dynamics of Dissolved Organic Matter in Soils: A Review. Soil Science, 165, 277-304. https://doi.org/10.1097/00010694-200004000-00001

[129] Tomlinson, A., Drikas, M. and Brookes, J.D. (2016) The Role of Phytoplankton as Precursors for Disinfection By-Product Formation upon Chlorination. Water Research, 102, 229-240. https://doi.org/10.1016/j.watres.2016.06.024

[130] Pivokonsky, M., Kloucek, O. and Pivokonska, L. (2006) Evaluation of the Production, Composition and Aluminum and Iron Complexation of Algogenic Organic Matter. Water Research, 40, 3045-3052. https://doi.org/10.1016/j.watres.2006.06.028

[131] Henderson, R.K., Baker, A., Parsons, S.A. and Jefferson, B. (2008) Characterisation of Algogenic Organic Matter Extracted from Cyanobacteria, Green Algae and Diatoms. Water Research, 42, 3435-3445. https://doi.org/10.1016/j.watres.2007.10.032

[132] Nguyen, M.-L., Baker, L.A. and Westerhoff, P. (2002) DOC and DBP Precursors in Western US Watersheds and Reservoirs. Journal of the American Water Works Association, 94, 98-112. https://doi.org/10.1002/j.1551-8833.2002.tb09474.x

[133] Zhou, S., Shao, Y., Gao, N., Deng, Y., Li, L., Deng, J. and Tan, C. (2014) Characterization of Algal Organic Matters of Microcystis aeruginosa: Biodegradability, DBP Formation and Membrane Fouling Potential. Water Research, 52, 199-207. https://doi.org/10.1016/j.watres.2014.01.002

[134] Wetzel, R.G. (1992) Gradient-Dominated Ecosystems: Sources and Regulatory Functions of Dissolved Organic Matter in Freshwater Ecosystems. Hydrobiologia, 229, 181-198. https://doi.org/10.1007/BF00007000

[135] Imai, A., Fukushima, T., Matsushige, K. and Kim, Y.H. (2001) Fractionation and Characterization of Dissolved Organic Matter in a Shallow Eutrophic Lake, Its Inflowing Rivers, and Other Organic Matter Sources. Water Research, 35, 4019-4028. https://doi.org/10.1016/S0043-1354(01)00139-7

[136] Mitch, W.A., Krasner, S.W., Westerhoff, P. and Dotson, A. (2009) Occurrence and Formation of Nitrogenous Disinfection By-Products. Report Number 91250. Water Research Foundation, Denver.

[137] Reckhow, D.A., Rees, P.L., Nüsslein, K., Makdissy, G., Devine, G., Conneely, T., Boutin, A. and Bryan, D. (2007) Long-Term Variability of BDOM and NOM as Precursors in Watershed Sources. Report Number 91186. AWWA Research Foundation, Denver.

[138] Eckhardt, B.W. and Moore, T.R. (1990) Controls on Dissolved Organic Carbon Concentrations in Streams, Southern Quebec. Canadian Journal of Fisheries and Aquatic Sciences, 47, 1537-1544. https://doi.org/10.1139/f90-173

[139] Kerekes, J., Howell, G., Beauchamp, S. and Pollock, T. (1982) Characterization of Three Lake Basins Sensitive to Acid Precipitation in Central Nova Scotia (June, 1979 to May, 1980). Internationale Revue der gesamten Hydrobiologie, 67, 679-694.

[140] Curtis, P.J. and Adams, H.E. (1995) Dissolved Organic Matter Quantity and Quality from Freshwater and Saltwater Lakes in East-Central Alberta. Biogeochemistry, 30, 59-76. https://doi.org/10.1007/BF02181040 
[141] Thorstenson, D.C., Fisher, D.W. and Croft, M.G. (1979) The Geochemistry of the Fox Hills-Basal Hell Creek Aquifer in Southwestern North Dakota and Northwestern South Dakota. Water Resources Research, 15, 1479-1498. https://doi.org/10.1029/WR015i006p01479

[142] Aravena, R., Wassenaar, L.I. and Barker, J.F. (1995) Distribution and Isotopic Characterization of Methane in a Confined Aquifer in Southern Ontario, Canada. Journal of Hydrology, 173, 51-70. https://doi.org/10.1016/0022-1694(95)02721-Z

[143] Diem, S., Von Rohr, M.R., Hering, J.G., Kohler, H.-E., Schirmer, M. and Von Gunten, U. (2013) NOM Degradation during River Infiltration: Effects of the Climate Variables Temperature and Discharge. Water Research, 47, 6585-6595. https://doi.org/10.1016/j.watres.2013.08.028

[144] Tubić, A., Agbaba, J., Dalmacija, B., Molnar, J., Maletic, S., Watson, M. and Perovic, S.U. (2013) Insight into Changes during Coagulation in NOM Reactivity for Trihalomethanes and Haloacetic Acids Formation. Journal of Environmental Management, 118, 153-160. https://doi.org/10.1016/j.jenvman.2012.11.046

[145] Ghernaout, D. (2020) Water Treatment Coagulation: Dares and Trends. Open Access Library Journal, 7, e6636.

[146] Ghernaout, D., Aichouni, M. and Alghamdi, A. (2018) Overlapping ISO/IEC 17025:2017 into Big Data: A Review and Perspectives. International Journal of Science and Qualitative Analysis, 4, 83-92.

[147] Ghernaout, D., Aichouni, M., Alghamdi, A. and Ait Messaoudene, N. (2018) Big Data: Myths, Realities and Perspectives-A Remote Look. American Journal of Information Science and Technology, 2, 1-8. https://doi.org/10.11648/j.ajist.20180201.11

[148] Montreuil, K.R. (2011) Natural Organic Matter Characterization in Drinking Water. M.A. Sc. Thesis, Dalhousie University, Halifax.

[149] Goss, C.D. and Gorczyca, B. (2013) Trihalomethane Formation Potential of DOC Fractions Isolated from Two Canadian Prairie Surface Water Sources. Water Science and Technology: Water Supply, 13, 114-122.

https://doi.org/10.2166/ws.2012.093

[150] Ekström, S.M., Kritzberg, E.S., Kleja, D.B., Larsson, N., Nilsson, P.A., Graneli, W. and Bergkvist, B. (2011) Effect of Acid Deposition on Quantity and Quality of Dissolved Organic Matter in Soil-Water. Environmental Science \& Technology, 45, 4733-4739. https://doi.org/10.1021/es104126f

[151] Ghernaout, D., Ghernaout, B. and Boucherit, A. (2008) Effect of pH on Electrocoagulation of Bentonite Suspensions in Batch Using Iron Electrodes. Journal of Dispersion Science and Technology, 29, 1272-1275. https://doi.org/10.1080/01932690701857483

[152] Ghernaout, D. (2017) The Holy Koran Revelation: Iron Is a "Sent Down" Metal. American Journal of Environmental Protection, 6, 101-104. https://doi.org/10.11648/j.ajep.20170604.14

[153] Black, A.P. and Christman, R.F. (1963) Characteristics of Colored Surface Waters. Journal of the American Water Works Association, 55, 753-770. https://doi.org/10.1002/j.1551-8833.1963.tb01085.x

[154] Anderson, L.E., Krkošek, W.H., Stoddart, A.K., Trueman, B.F. and Gagnon, G.A. (2017) Lake Recovery through Reduced Sulfate Deposition: A New Paradigm for Drinking Water Treatment. Environmental Science \& Technology, 51, 1414-1422. https://doi.org/10.1021/acs.est.6b04889

[155] Parsons, S.A., Jefferson, B., Jarvis, P., Sharp, E., Dixon, D., Bolto, B. and Scales, P. 
(2007) Treatment of Waters with Elevated Organic Carbon. Report Number 91161. AWWA Research Foundation, Denver.

[156] Eikebrokk, B., Vogt, R.D. and Liltved, H. (2004) NOM Increase in Northern European Source Waters: Discussion of Possible Causes and Impacts on Coagulation/Contact Filtration Processes. Water Science and Technology: Water Supply, 4, 47-54. https://doi.org/10.2166/ws.2004.0060

[157] Sharp, E.L., Parsons, S.A. and Jefferson, B. (2006) Seasonal Variations in Natural Organic Matter and Its Impact on Coagulation in Water Treatment. Science of the Total Environment, 363, 183-194. https://doi.org/10.1016/j.scitotenv.2005.05.032

[158] Emelko, M.B. (2019) Modeling Critical Infrastructure Inter-Dependencies: Considering Drinking Water Treatability for Climate Change Adaption. CWWA Window on Ottawa, Ottawa.

[159] van der Linden, L., Burch, M., Chang, C.-H., Lin, T.-F., Baradouzi, M.A., Moglen, G., Godrej, A., Little, J. and Brookes, J. (2018) Assessment of Climate Change on Reservoir Water Quality. Project 4468. Water Research Foundation, Denver.

[160] Shin, J.Y., Spinette, R.F. and O’Melia, C.R. (2008) Stoichiometry of Coagulation Revisited. Environmental Science \& Technology, 42, 2582-2589.

https://doi.org/10.1021/es071536o

[161] Carlson, K.H. and Gregory, D. (2000) Optimizing Water Treatment with Two-Stage Coagulation. Journal of Environmental Engineering, 126, 556-561. https://doi.org/10.1061/(ASCE)0733-9372(2000)126:6(556)

[162] Bond, T., Huang, J., Graham, N.J.D. and Templeton, M.R. (2014) Examining the Interrelationship between DOC, Bromide and Chlorine Dose on DBP Formation in Drinking Water-A Case Study. Science of the Total Environment, 470-471, 469-479. https://doi.org/10.1016/j.scitotenv.2013.09.106

[163] Hua, G., Kim, J. and Reckhow, D.A. (2014) Disinfection Byproduct Formation from Lignin Precursors. Water Research, 63, 285-295. https://doi.org/10.1016/j.watres.2014.06.029

[164] Stalter, D., O’Malley, E., von Gunten, U. and Escher, B.I. (2016) Fingerprinting the Reactive Toxicity Pathways of 50 Drinking Water Disinfection By-Products. Water Research, 91, 19-30. https://doi.org/10.1016/j.watres.2015.12.047

[165] Vu, B., Chen, M., Crawford, R.J. and Ivanova, E.P. (2009) Bacterial Extracellular Polysaccharides Involved in Biofilm Formation. Molecules, 14, 2535-2554. https://doi.org/10.3390/molecules14072535

[166] Zhou, E., Payne, S.J.O., Hofmann, R. and Andrews, R.C. (2015) Factors Affecting Lead Release in Sodium Silicate-Treated Partial Lead Service Line Replacements. Journal of Environmental Science and Health, Part A: Toxic/ Hazardous Substances and Environmental Engineering, 50, 922-930.

[167] Rigobello, E.S., Dantas, A.D., Di Bernardo, L. and Vieira, E.M. (2011) Influence of the Apparent Molecular Size of Aquatic Humic Substances on Colour Removal by Coagulation and Filtration. Environmental Technology, 33, 1767-1777. https://doi.org/10.1080/09593330.2011.555423

[168] McVicar, M., Bickerton, B., Chaulk, M. and Walsh, M. (2015) UV $_{254}$ and Streaming Current Monitors Can Improve Coagulation Control in Challenging Conditions. Opflow, 41, 26-28. https://doi.org/10.5991/OPF.2015.41.0042

[169] Chon, K. and Cho, J. (2016) Fouling Behavior of Dissolved Organic Matter in Nanofiltration Membranes from a Pilot-Scale Drinking Water Treatment Plant: An Autopsy Study. Chemical Engineering Journal, 295, 268-277.

https://doi.org/10.1016/j.cej.2016.03.057 
[170] Rahman, I., Ndiongue, S., Jin, X., Van Dyke, M.I., Anderson, W.B. and Huck, P.M. (2014) Fouling of Low-Pressure Membranes during Drinking Water Treatment: Effect of NOM Components and Biofiltration Pretreatment. Water Science \& Technology Water Supply, 14, 453-460. https://doi.org/10.2166/ws.2013.221

[171] Her, N., Amy, G., Plottu-Pecheux, A. and Yoon, Y. (2007) Identification of Nanofiltration Membrane Foulants. Water Research, 41, 3936-3947. https://doi.org/10.1016/j.watres.2007.05.015

[172] Siembida-Lösch, B., Anderson, W.B., Wang, Y., Bonsteel, J. and Huck, P.M. (2015) Effect of Ozone on Biopolymers in Biofiltration and Ultrafiltration Processes. Water Research, 70, 224-234. https://doi.org/10.1016/j.watres.2014.11.047

[173] Tan, L. and Sudak, R.G. (1992) Removing Color from a Groundwater Source. Journal of the American Water Works Association, 84, 79-87. https://doi.org/10.1002/j.1551-8833.1992.tb07288.x

[174] Ratnaweera, H., Gjessing, E. and Oug, E. (1999) Influence of Physical-Chemical Characteristics of Natural Organic Matter (NOM) on Coagulation Properties: An Analysis of Eight Norwegian Water Sources. Water Science \& Technology, 40, 89-95. https://doi.org/10.2166/wst.1999.0450

[175] Watson, S.B. (2003) Cyanobacterial and Eukaryotic Algal Odour Compounds: Signals or By-Products? A Review of Their Biological Activity. Phycologia, 42, 332-350. https://doi.org/10.2216/i0031-8884-42-4-332.1

[176] Zaitlin, B. and Watson, S.B. (2006) Actinomycetes in Relation to Taste and Odour in Drinking Water: Myths, Tenets and Truths. Water Research, 40, 1741-1753. https://doi.org/10.1016/j.watres.2006.02.024

[177] AWWA (2011) Diagnosing Taste and Odor Problems Field Guide. American Water Works Association, Denver.

[178] Volk, C., Wood, L., Johnson, B., Robinson, J., Zhu, H.W. and Kaplan, L. (2002) Monitoring Dissolved Organic Carbon in Surface and Drinking Waters. Journal of Environmental Monitoring, 4, 43-47. https://doi.org/10.1039/b107768f

[179] APHA/AWWA/WEF (2017) Standard Methods for the Examination of Water and Wastewater. 23rd Edition, American Public Health Association, American Water Works Association, Water Environment Federation, Washington DC, 9711D.

[180] Karanfil, T., Schlautman, M.A. and Erdogan, I. (2002) Survey of DOC and UV Measurement Practices with Implications for SUVA Determination. Journal of the American Water Works Association, 94, 68-80. https://doi.org/10.1002/j.1551-8833.2002.tb10250.x

[181] Minor, E.C., Swenson, M.M., Mattson, B.M. and Oyler, A.R. (2014) Structural Characterization of Dissolved Organic Matter: A Review of Current Techniques for Isolation and Analysis. Environmental Science: Processes \& Impacts, 16, 2064-2079. https://doi.org/10.1039/C4EM00062E

[182] Wright, B., Becker, W., Irving, J., Reinert, A., Stanford, B., Reckhow, D., Wittbold, P. and Zhao, R. (2016) Advanced Techniques for Monitoring Changes in NOM and Controlling DBPs under Dynamic Weather Conditions. Report Number 4422. Water Research Foundation, Denver.

[183] Bolton, J.R. (2013) Ultraviolet Applications Handbook. 3rd Edition, Bolton Photosciences Inc., Edmonton.

[184] Archer, A.D. and Singer, P.C. (2006) Effect of SUVA and Enhanced Coagulation on Removal of TOX Precursors. Journal of the American Water Works Association, 98, 97-107. https://doi.org/10.1002/j.1551-8833.2006.tb07737.x 
[185] Chow, C.W.K., Fabris, R., Drikas, M. and Holmes, M. (2005) A Case Study of Treatment Performance and Organic Character. Journal of Water Supply. Research and Technology-Aqua, 54, 385-395. https://doi.org/10.2166/aqua.2005.0036

[186] Hwang, C.J., Krasner, S.W., Sclimenti, M.J., Amy, G.L., Dickenson, E., Bruchet, A., Prompsy, C., Filippi, G., Croué, J.-P., Violleau, D. and Leenheer, J.A. (2001) Polar NOM: Characterization, DBPs, Treatment. Report Number 90877. AWWA Research Foundation, Denver.

[187] Summers, R.S., Beggs, K.M.H., McKnight, D.M., Rosario-Ortiz, F.L. and Billica, J.A. (2013) Watershed Analysis of Dissolved Organic Matter and Control of Disinfection By-Products. Report Number 4282. Water Research Foundation, Denver.

[188] Roccaro, P., Chang, H.-S., Vagliasindi, F.G.A. and Korshin, G.V. (2008) Differential Absorbance Study of Effects of Temperature on Chlorine Consumption and Formation of Disinfection By-Products in Chlorinated Water. Water Research, 42, 1879-1888. https://doi.org/10.1016/j.watres.2007.11.013

[189] Edzwald, J.K. and Kaminski, G.S. (2009) A Practical Method for Water Plants to Select Coagulant Dosing. Journal of the New England Water Works Association, $123,15-31$.

[190] U.S. EPA (2016) Six-Year Review 3 Technical Support Document for Disinfectants/Disinfection Byproducts Rules. Office of Water, U.S. Environmental Protection Agency, Washington DC. (EPA-810-R-16-012)

[191] Karanfil, T., Cheng, W., Guo, Y., Dastgheib, S.A. and Song, H. (2007) DBP Formation Control by Modified Activated Carbons. Report Number 91181. AWWA Research Foundation, Denver.

[192] Kristiana, I., Joll, C. and Heitz, A. (2011) Powdered Activated Carbon Coupled with Enhanced Coagulation for Natural Organic Matter Removal and Disinfection By-Product Control: Application in a Western Australian Water Treatment Plant. Chemosphere, 83, 661-667. https://doi.org/10.1016/j.chemosphere.2011.02.017

[193] Bond, T., Goslan, E.H., Parsons, S.A. and Jefferson, B. (2011) Treatment of Disinfection By-Product Precursors. Environmental Technology, 32, 1-25. https://doi.org/10.1080/09593330.2010.495138

[194] Ghernaout, D. (2020) Demobilizing Antibiotic-Resistant Bacteria and Antibiotic Resistance Genes by Electrochemical Technology: New Insights. Open Access Library Journal, 7, e6685. https://doi.org/10.4236/oalib.1106685

[195] Ghernaout, D. (2020) Electrocoagulation as a Pioneering Separation Technology-Electric Field Role. Open Access Library Journal, 7, e6702. 